\title{
From Naples 1963 to Rome 2013 - A brief review of how the International Research Group on Ostracoda (IRGO) developed as a social communication system
}

\author{
Dan L. Danielopol ${ }^{\mathrm{a}, *}$, Angel Baltanás ${ }^{\mathrm{b}}$, Pierre Carbonel ${ }^{\mathrm{c}}$, Jean-Paul Colin ${ }^{1}$, Sylvie Crasquin ${ }^{\mathrm{d}}$, Laurent Decrouy ${ }^{\mathrm{e}}$, \\ Patrick De Deckker ${ }^{\mathrm{f}}$, Elsa Gliozzi ${ }^{\mathrm{g}}$, Helga Groos-Uffenorde ${ }^{\mathrm{h}}$, David J. Horne ${ }^{\mathrm{i}}$, Sanda Iepure ${ }^{\mathrm{j}, \mathrm{k}}$, Dietmar Keyser ${ }^{\text {', }}$ \\ Louis S. Kornicker ${ }^{\mathrm{m}}$, Alan Lord ${ }^{\mathrm{n}}$, Koen Martens ${ }^{\mathrm{o}}$, Renate Matzke-Karasz ${ }^{\mathrm{p}}$, C. Giles Miller ${ }^{\mathrm{q}}$, Henri J. Oertli ${ }^{\mathrm{r}}$, \\ Nevio Pugliese ${ }^{\mathrm{s}}$, Antonio Russo ${ }^{\mathrm{t}}$, Benjamin Sames ${ }^{\mathrm{u}}$, Isa Schön ${ }^{\circ}$, David J. Siveter ${ }^{\mathrm{v}}$, Alison Smith ${ }^{\mathrm{w}}$, \\ Finn A. Viehberg ${ }^{\mathrm{x}}$, Karel Wouters ${ }^{\mathrm{y}}$, Iradj Yassini ${ }^{\mathrm{z}}$
}

a Department of Geology and Palaeontology, Institute of Earth Sciences, Karl-Franzens University, Heinrichstr. 26, A-8010 Graz, Austria

b Department of Ecology, Faculty of Sciences, Universidad Autónoma de Madrid, E-28049 Madrid, Spain

c 16, rue Mégret, F-33400 Talence, France

${ }^{d}$ Centre de recherches sur la paléobiodiversité et les paléoenvironnements, Université Paris-6, CNRS-MNHN, T. 46-56, E. 5, case 104, 4 Place Jussieu, F-75252 Paris cedex 05, France

e Institute of Earth Surface Dynamics, Faculty of Geosciences and Environment, University of Lausanne, CH-1015 Lausanne, Switzerland

${ }^{\mathrm{f}}$ Research School of Earth Sciences, The Australian National University, Canberra, ACT 0200, Australia

${ }^{g}$ Department of Science, University of Roma Tre, Largo S. Leonardo Murialdo 1, I-00146 Rome, Italy

${ }^{\text {h }}$ Geoscience Center, University of Goettingen, Goldschmidt-Str. 3, D-37077 Göttingen, Germany

i School of Geography, Queen Mary University of London, Mile End Road, London E1 4NS, UK

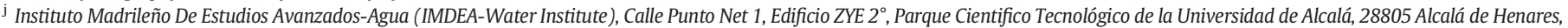
Madrid, Spain

k “Emil Racoviță" Institute of Speleology, Romanian Academy, Clinicilor 5, 400006 Cluj Napoca, Romania

${ }^{1}$ Zoological Institute and Museum, Biozentrum Grindel, University Hamburg, Martin-Luther King Platz 3, D-20146 Hamburg, Germany

m 10400 Lake Ridge Drive, Oakton, VA 22124, USA

n Senckenberg Forschungsinstitut und Naturmuseum, Senckenberganlage 25, D-60325 Frankfurt-am-Main, Germany

${ }^{\circ}$ Freshwater Biology, Royal Belgian Institute of Natural Sciences, Vautierstraat 29, B-1000 Brussels, Belgium

${ }^{\mathrm{P}}$ Department of Earth and Environmental Sciences, Palaeontology and Geobiology, GeoBio-Center, Ludwig-Maximilians-University München, Richard-Wagner-Str. 10, D-80333 München, Germany

${ }^{q}$ Department of Earth Science, Natural History Museum, Cromwell Road, London SW7 7BD, UK

${ }^{\mathrm{r}} 14$ avenue des Écureuils, F-56530 Gestel, France

s Department of Mathematics and Geosciences, University of Triest, Via Weiss 2, I-34128 Triest, Italy

t Viale Ludovico Muratori, 225, I-41124 Modena, Italy

u Department for Geodynamics and Sedimentology, Institute for Palaeontology, Geozentrum, University of Vienna, Althanstrasse 14, A-1090 Vienna, Austria

${ }^{v}$ Department of Geology, University of Leicester, University Road, Leicester LE1 7RH, UK

${ }^{w}$ Department of Geology, Kent State University, $\mathrm{OH} 44242$, USA

x Institute of Geology and Mineralogy, University of Cologne, Zülpicher Strasse 49A, D-50674 Cologne, Germany

${ }^{y}$ Department of Invertebrates, Royal Belgian Institute of Natural Sciences, Vautierstraat 29, B-1000 Brussels, Belgium

${ }^{z}$ Wollongong City Council, Locked Bag 8821, Wollongong DC, NSW 2500, Australia

\section{A R T I C L E I N F O}

\section{Article history:}

Received 6 March 2014

Received in revised form 1 August 2014

Accepted 7 August 2014

Available online 28 August 2014

\section{A B S T R A C T}

The 1st International Symposium on Ostracoda (ISO) was held in Naples (1963). The philosophy behind this symposium and the logical outcome of what is now known as the International Research Group on Ostracoda (IRGO) are here reviewed, namely ostracodology over the last 50 years is sociologically analysed. Three different and important historic moments for the scientific achievements of this domain are recognised. The first one, between about 1963 and 1983, is related to applied research for the oil industry as well as to the great interest in the better

\footnotetext{
* Corresponding author.

E-mail addresses: dan.danielopol@uni-graz.at (D.L. Danielopol), angel.baltanas@uam.es (A. Baltanás), carbonel@free.fr (P. Carbonel), sylvie.crasquin@upmc.fr (S.Crasquin),

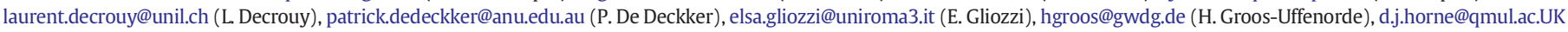
(D.J. Horne), sanda.iepure@imdea.org (S. Iepure), keyser@zoologie.uni-hamburg.de (D. Keyser), alan.lord@senckenberg.de (A. Lord), koen.martens@naturalsciences.be (K. Martens), r.matzke@lrz.uni-muenchen.de (R. Matzke-Karasz),g.miller@nhm.ac.uk (C. Giles Miller), hkoertli@yahoo.fr (H.J. Oertli), pugliese@units.it (N. Pugliese), antonio.russo1940@gmail.com (A. Russo), benjamin.sames@univie.ac.at (B. Sames), isa.schoen@naturalsciences.be (I. Schön), djs@le.ac.uk (D.J. Siveter), alisonjs@kent.edu (A. Smith), finn.viehberg@uni-koeln.de (F.A. Viehberg), karel.wouters@naturalsciences.be (K. Wouters), iYassini@wollongong.nsw.gov.au (I. Yassini).

${ }^{1}$ Jean-Paul Colin unexpectedly died on 17 September 2013.
} 
Keywords:

Ostracodology-developments

Ostracodologists scientific-community

Sociologic analysis description of the marine environment by both zoologists and palaeontologists. Another important aspect during this period was the work by researchers dealing with Palaeozoic ostracods, who had their own discussion group, IRGPO. Gradually, the merger of this latter group with those dealing with post-Palaeozoic ostracods at various meetings improved the communication between the two groups of specialists. A second period was approximately delineated between 1983 and 2003. During this time-slice, more emphasis was addressed to environmental research with topics such as the study of global events and long-term climate change. Ostracodologists profited also from the research "politics" within national and international programmes. Large international research teams emerged using new research methods. During the third period (2003-2013), communication and collaborative research reached a global dimension. Amongst the topics of research we cite the reconstruction of palaeoclimate using transfer functions, the building of large datasets of ostracod distributions for regional and intercontinental studies, and the implementation of actions that should lead to taxonomic harmonisation. Projects within which molecular biological techniques are routinely used, combined with sophisticated morphological information, expanded now in their importance. The documentation of the ostracod description improved through new techniques to visualise morphological details, which stimulated also communication between ostracodologists. Efforts of making available ostracod information through newsletters and electronic media are evoked.

(c) 2014 Elsevier B.V. All rights reserved.

\section{Introduction}

The subject we present here has different motivations and the way we will develop them will certainly surprise. Hence a necessary explanation follows below.

Professor Gioacchino Bonaduce, one of the main contributors to the first ostracod meeting held in 1963 in Naples, proposed during the 3rd European Ostracodologists' Meeting, hosted in Bierville, France, 1996, to organise in Italy another International Symposium on Ostracoda (ISO) at the beginning of the new century. The idea was to honour the memory of the enthusiastic generation of ostracodologists who launched at the 1963 meeting in Naples a vast programme dealing with collaborative work on ostracods. The initial working-group was the Committee on Recent Ostracoda, which later became what we now call the "International Research Group on Ostracoda" (IRGO). Through its activities, ostracodology became a synthetic research venture which progressed steadily. The Bonaduce proposal was realised 2013 with the organisation of the 17th ISO-meeting in Rome (Italian Ostracodologists' Group, International Research Group on Ostracoda, 2013).

During a discussion that started in April 2012 on the e-mail listserver OSTRACON concerning the present status of specialists working on ostracods, it was noted that the number of ostracodologists worldwide had diminished in recent years, and this situation could be related to unfavourable politics of funding scientific research in many countries. It was the idea of one of us (DLD) to review the development of the ostracod workers' community, now called IRGO, over the last 50 years, namely to follow the important moments of the scientific research within a sociologic framework. We decided to restrict our project to a synthetic exposé for which a number of colleagues agreed to contribute with their own records and personal views on the various moments in the development of ostracodology during the 50 year period. The preparation of the review was managed as a co-inspiring project by a number of colleagues who collectively were named Ostracodophili (the ostracod lovers). This review with the title used here was the opening lecture to the 17th ISO convention (Ostracodophili, 2013). Besides the various written contributions offered by the authors of this review, ${ }^{2}$

\footnotetext{
2 Below are acronyms for the 27 authors of the review used in the text and/or with which we refer to their written contribution deposited in the Supplementary datasection (Sd): D. L. Danielopol (DLD.), A. Baltanás (AB), P. Carbonel (PC), J-P. Colin (JPC), S. Crasquin (SC), P. De Deckker (PDD), L. Decrouy (LD), E. Gliozzi (EG), H. GroosUffenorde (HGU), D. J. Horne (DJH), S. Iepure (SI), D. Keyser (DK), L. S. Kornicker (LSK), A. Lord (AL), K. Martens (KM), R. Matzke-Karasz (RMK), C. G. Miller (GM), H. J. Oertli (HJO), N. Pugliese (NP), A. Russo (AR), B. Sames (BS), I. Schön (IS), David J. Siveter (DJS), A. Smith (AS), F. Viehberg (FV), K. Wouters (KW), I. Yassini (IY). Sd - Supplementary data, are available only in the on-line version of this issue. Note that $\mathrm{DK}(\mathrm{P})$ and $\mathrm{DK}(\mathrm{H})$ send to the Supplementary data for the information on H.S. Puri (P) and G. Hartmann (H); similar for DJS, namely (I) refers to the information on Imaging and (C) on Communication.
}

information and photographic material was received from several other "Ostracodophili" (below ${ }^{3}$ their names).

Sociology of scientific research is a subject that was not expressly dealt with during previous ostracod conferences. We noted that international symposia on Ostracoda usually open with invited lectures providing the state-of-the-art of Ostracodology or with selected themes of high topicality. As examples, we mention the key lectures offered to the 8th ISO-meeting in Houston, 1982: Kesling (1983) spoke on ostracodology in 1982, Kaesler (1983) discussed the usefulness of Ostracoda and Oertli et al. (1983) reviewed the use of Ostracoda in petroleum exploration. Therefore we consider our present review as an innovative topic that should contribute to the above-mentioned discussion opened by the colleagues on the OSTRACON-platform during 2012. Our discourse should honour some of the ostracodologists who contributed in a significant way to the progress of Ostracodology during this half-century period. Finally, this review will offer to the young generation of ostracod researchers some ideas of how to succeed within the next period of time, taking into account the many difficulties with which ostracodologists are nowadays confronted. Our essay presents aspects for which one could use metaphorically the title given by the French artist Paul Gauguin in 1897 to one of his paintings, now exposed in the Museum of Fine Arts, in Boston, Ma., Where do we come from? What are we? Where are we going?

\section{What is Ostracodology?}

We define Ostracodology, by analogy with the way the Austrian physicist H. Pietschmann (1996) defined physics, as a special domain of research, therefore "Ostracodology is what ostracodologists are doing". Pietschmann showed that the circularity of such a definition is broken if we add an aspect of the social context, the community of scientists with its dynamics. This latter aspect becomes visible in the congresses attended by the interested group of scientists as well in their way of discussing and/or publishing their data.

Coming back to the way ostracod research historically developed one could say that Ostracodology began with a "Heroic Period" (a metaphorical term proposed by AL in Sd). For this incipient stage of Ostracodology one should mention the remarkable research of O. F. Müller at the end of the 18th century (Oertli, 1982) that was continued in the whole period of the 19th century and the first half of the last century (Neale, 1988). The main interest of natural scientists during this so-called Heroic Period was to catalogue and morphologically describe the surprisingly rich ostracod fauna from both marine and limnic environments. As

${ }^{3}$ J. Athersuch (Ottershaw, Surrey), E. Browers (Boulder, CO), A. Cohen (San Rafael, CA), Cl. Guernet (Paris), V. Hajek-Tadesse (Zagreb), A. Honigstein (Jerusalem), E. Kempf (Cologne), R. Maddocks (Houston, TX), M. Maja (Naples), T. Namiotko (Gdansk), R. Pipik (Banská Bystrica), L. Rundić (Belgrade), E. Schornikov (Vladivostok), F. Sgarrella (Naples), M. Stoica (Bucharest), E. Tesakova (Moscow), A. Yuan (Wuhan City), D. Zhai (Beijing). 
examples of ostracodological achievements, we will mention the monograph of G. S. Brady (1880) for the deep-sea ostracods, that of Müller (1894) for the Mediterranean ostracods within the Bay of Naples, and the G. O. Sars monograph on the ostracods of Norway (Sars, 1922-1928). ${ }^{4}$

With the first Ostracod Symposium in Naples, 1963 (Puri (1964)) begins the "Modern Science of Ostracodology". An excellent evaluation of the research presented from the first Ostracod Meeting in Naples to the fifteenth International Symposium on Ostracoda, in Berlin, 2005, was offered by Matzke-Karasz et al. (2007). While their publication deals with the dynamics of ostracod research related to main biological topics, like taxonomy, phylogeny, (palaeo)ecology, (palaeo)biogeography, biostratigraphy as presented during the 15 ISO meetings by members of the IRGO, we will take here a different approach, namely analysing the development of the ostracod research during the last 50 years, related to the social relationships of the IRGO members and of the sociological context of their activities. As in a theatre play we will present the ostracodological developments as a succession of historical scenes, where the ostracodologists are the actors.

Fig. 1 shows the incremental growth of publishing ostracodologists and their geographic distribution. One should note the blatant difference between the Heroic Period and the Modern one, but within this latter there are differences in the frequency of publications between different geographic areas. We will see next, that such differences can be related to social aspects faced by ostracodologists worldwide. Therefore, to objectively describe such differences in term of human social relationships and/or socio/political aspects of their activities during certain historical moments we need sociological tools. These latter already exist, as they were developed during the last 30-40 years for other domains of scientific research.

The 50 year period of the so-called "Modern Science of Ostracodology" will be divided for the purpose of this review in three periods:

- First period (1963- 1983), dominated by a general expansion of ostracodology and where the application of ostracod expertise to petroleum research played inter alia a significant role.

- Second period ( 1983- 2003), orientated more towards environmental aspects.

- Third period ( 2003-2013), which continues previous trends, is exploring new ways of introducing ostracod knowledge within global science.

\section{Methods used for the sociological analysis of IRGO}

Initially, we considered that a social system is a communication system structured by communication acts related to their research motivations (Koch, 2005). Therefore, we looked at the dynamics of the ostracodologist community and how ostracodologists communicated during the time. Sohn (1977), in his essay presented at ISO-6, mapped the distribution of ostracodologists of the world (as known in 1976) and classified ostracodologist communities on a country-basis and by research-motivation. From these data, Sohn speculated on the factors explaining the origin of ostracodologists' communities, namely their employment and their interest for environmentalism. During the 1940s-1970s, the ostracodologist communities were mainly related to petroleum research, best developed in the United States and the Soviet Union. After 1970, the number of ostracodologists dealing with ostracods within environmental projects started to increase.

For the present review, the social activities of ostracodologists through an ethnographic approach were explored, namely by interviewing representative researchers on the cultural activity they experienced during the years. It was started with specialists who participated to the first Ostracod meeting in Naples 1963 and continued

\footnotetext{
${ }^{4}$ Details on the references here quoted can be found in the "Index and bibliography of marine Ostracoda" and in "Index and bibliography of non-marine Ostracoda" (Kempf Database Ostracoda (Kempf, 1980-2013)).
}

with those who contributed to the next ISO meetings, especially the ISO-2 in Hull, 1967 and ISO-3 in Pau, 1970. Under the term 'culture' we refer to the environment within which creative activities of man take place (Heidegger, 1986). In our present case, we asked what kind of scientific communication existed between and/or within given ostracodologist groups at specific moments. We also investigated which type of work was required within the different laboratories and companies. Additionally, we noted that social relationships between ostracodologists developed also around the method of study used or around selected taxa. The information received from 26 colleagues has been collated under each author's name in the Supplementary data (Sd) section. These colleagues were also invited to share the coauthorship of this review. The data allowed us to construct sociological profiles for several research groups. The type of investigation used is what in sociological research one calls narrative approach (Koerten and Veenswijk, 2010). The narrative approach as conceptualised in Koerten and Veenswijk is about "scenes, actors and actions" (Fig. 2). The scenes (or narrative episodes) are viewed through narrative settings, i.e. the general environment within which researchers live and work. The actors, as social groups, build a narrative space. The actions (or practice) of scientific groups with their scientific work constitute the third social block, named narrative storyboards. All three social modules interact and allow understanding for a specific period (episode) the scientific developments within the socio/political context. Moreover, we will examine the cultural leadership of given ostracodologists who during particular episodes played a decisive role in the advancement of ostracod research. The Supplementary datasection (Sd) presents brief reviews of scientific careers of well-known ostracodologists, or of some of us, we consider representative for a given period. One of the aims of this approach, would be to influence young ostracodologists to adopt a reflective position, namely to critically examine their present research status with the aim of foreseeing new strategic research developments. We should ask, for instance, what is the role we are playing in Science? Are we ahead or behind accepted "top" scientific activities? How much of our scientific output can be offered to a bright interested and/or educated public? In other words, how much from our creative scientific ideas represent societal cultural contributions. This parallels the quotation from "Behind Appearance" of C. H. Waddington (1969): “...new developments in any particular field only become part of the general culture of the world when they enter the experience of people who are not specialists in that area".

Besides the narrative approach, we adopted for our sociological study ideas developed by Latour and Woolgar (1979) and Latour (2005). These latter scientists developed the so-called Actor-Network Theory (ANT), an approach that helps explain how scientific networks develop and steadily change by the virtue of the dynamic relations of their actors (or Actants in the Latour's formulation). ANT considers social networks as formed by both human and non-human actors. Under this latter concept aspects of the environment are understood, such as research methodologies or technical devices. Non-human actants play as important a role as the human one in the development and/or in the dynamics of social networks. We will see here the importance for creative networks of the activity of ostracodologists who participated in the development of new methods, for illustration, or for (palaeo) environmental reconstructions, and/or for evolutionary studies. Besides the ethnographic research, ANT also examines what Latour (2005) calls Inscriptions, namely bibliographic data, images and/or databases.

\section{The first International Symposium on Ostracoda, organised at Stazione Zoologica “Anton Dohrn”, Naples, 10-19 June, 1963}

Within the first part of the 20th century, ostracod knowledge increased through basic research (e.g. taxonomy, geographic distribution) and applied research (e.g. ostracod studies for oil exploration). During the 1950-1960 period, it became necessary to improve the taxonomic and/or (palaeo)ecologic knowledge of Ostracoda in order to better use 


\section{Distribution of Publishing Ostracodologists}

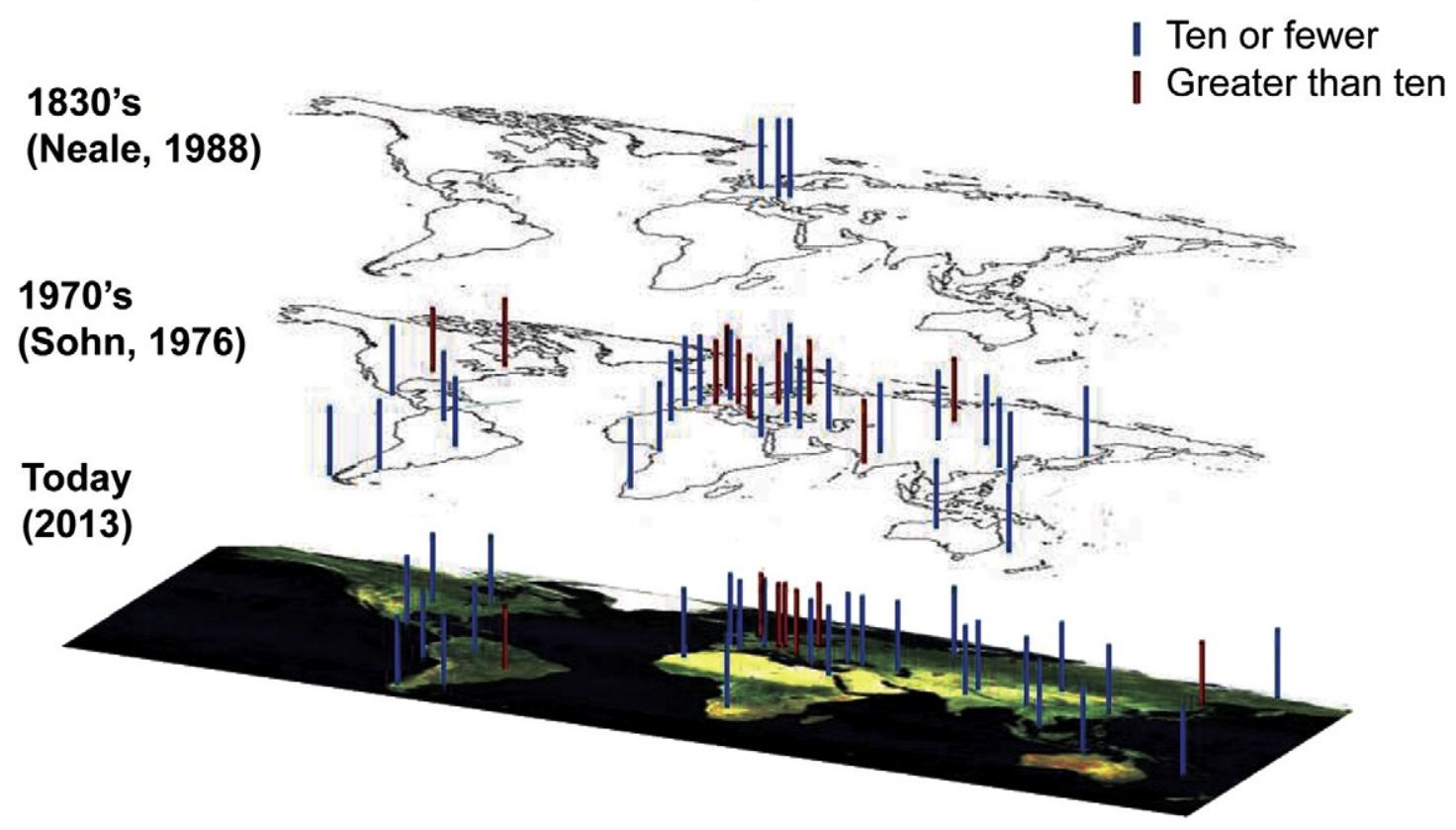

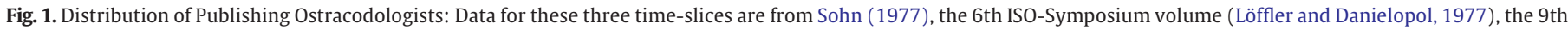
ISO-Symposium volume (Hanai et al., 1988) and the most recent Cypris Newsletter No. 30 (2012-2013). The map is modified from www.esa.net. (Credit: AS).

them for the two aims mentioned above. Description and illustration of fossil ostracods during this time was in many cases of limited quality despite its pressing interest. Erich Triebel's illustrations were an exception (see next sections). Harbans S. Puri, an American palaeontologist from the Florida Geological Survey, received from the American National Science Foundation between 1961 and 1963 yearly grants to work in Naples, at the Stazione Zoologica "Anton Dohrn", in order to revise and, if possible, to improve information on the taxonomy and ecological distribution of the ostracod fauna of Bay of Naples, described by G.W. Müller in his well-known monograph (Müller, 1894). This new information was expected to be a useful reference for other marine sites in Europe and North America (M. Maja, written communication to DLD). Having advanced this project, Puri in cooperation with the young Italian palaeontologist Gioacchino Bonaduce, at the time an assistant at the Stazione Zoologica in Naples, decided in 1963 to convene an international meeting with the theme "Ostracods as ecological and paleoecological

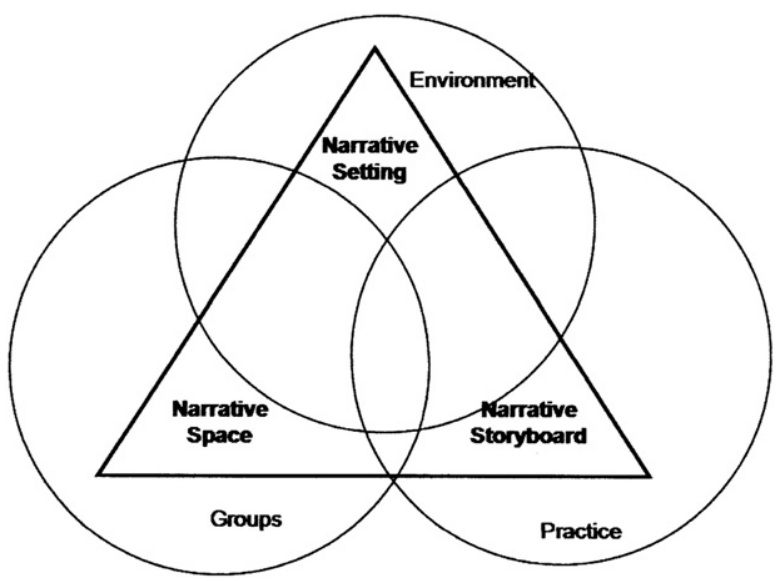

Fig. 2. Theoretical view of the Narrative Approach (from Koerten and Veenswijk, 2010, with permission). indicators". At the symposium, 28 specialists attended, with 23 ostracodologists from 11 countries (Fig. 3).

During the 10 days, topics related to morphology, ecology and to the taxonomic system of Recent and fossil ostracods were discussed. The presentations were followed by in-depth discussions from which emerged a general consensus of the necessity to create an international research group on Ostracoda which would keep contact through active communication and effective scientific exchanges of material and ideas. A volume edited by Puri (1964) contained 20 presentations and the round-table discussions grouped into six sessions. From the scientists who presented communications we should mention G. Hartmann who offered a unified classification system for recent and fossil ostracods (Hartmann, 1964), expanded later by Hartmann and Puri (1974) in a widely quoted publication. H. S. Puri and G. Hartmann played an active role in the discussions dealing not only with systematics but also with ecological distribution of marine ostracods [DK(P) in Sd; $\mathrm{DK}(\mathrm{H})$ in $\mathrm{Sd}]$. Another activity that merits mention is the election of R. H. Benson to develop a data-bank for ostracods, stored on I.B.M. punch-cards. This idea was not successful but a little later E. Kempf started a similar project, thus leading to the Kempf's Cologne Database for ostracods (Kempf, 1980-2013). We should also mention the initiative of $\mathrm{H}$. J. Oertli who stimulated a discussion on the usage of terms for salinity, using the so-called "Venice System". Amongst the participants with extraordinary capacity for communication was G. Ruggieri who later had a long-term cooperation with R. H. Benson and P. C. Sylvester-Bradley, contributing to the development of a scenario which described the so-called "Salinity Crisis of the Proto-Mediterranean" or the so-called "Lago Mare" (AR in Sd). Another participant, E. Gerry proposed a newsletter with information for ostracod researchers. It was called "The Ostracodologist" and was issued by Gerry over the following 20 years (RMK and FV in Sd).

Interestingly, in September 1963, the palaeontologist O. S. Vyalov organised in Lvov, Soviet Union (today's Ukraine) the First All Union Ostracod Symposium with 112 attendees. The Proceedings of the conference was published in Russian in 1966 and later on translated into English (Vyalov, 1971). Unfortunately, no other ostracod meeting was organised during the following years in the Soviet Union, and the 


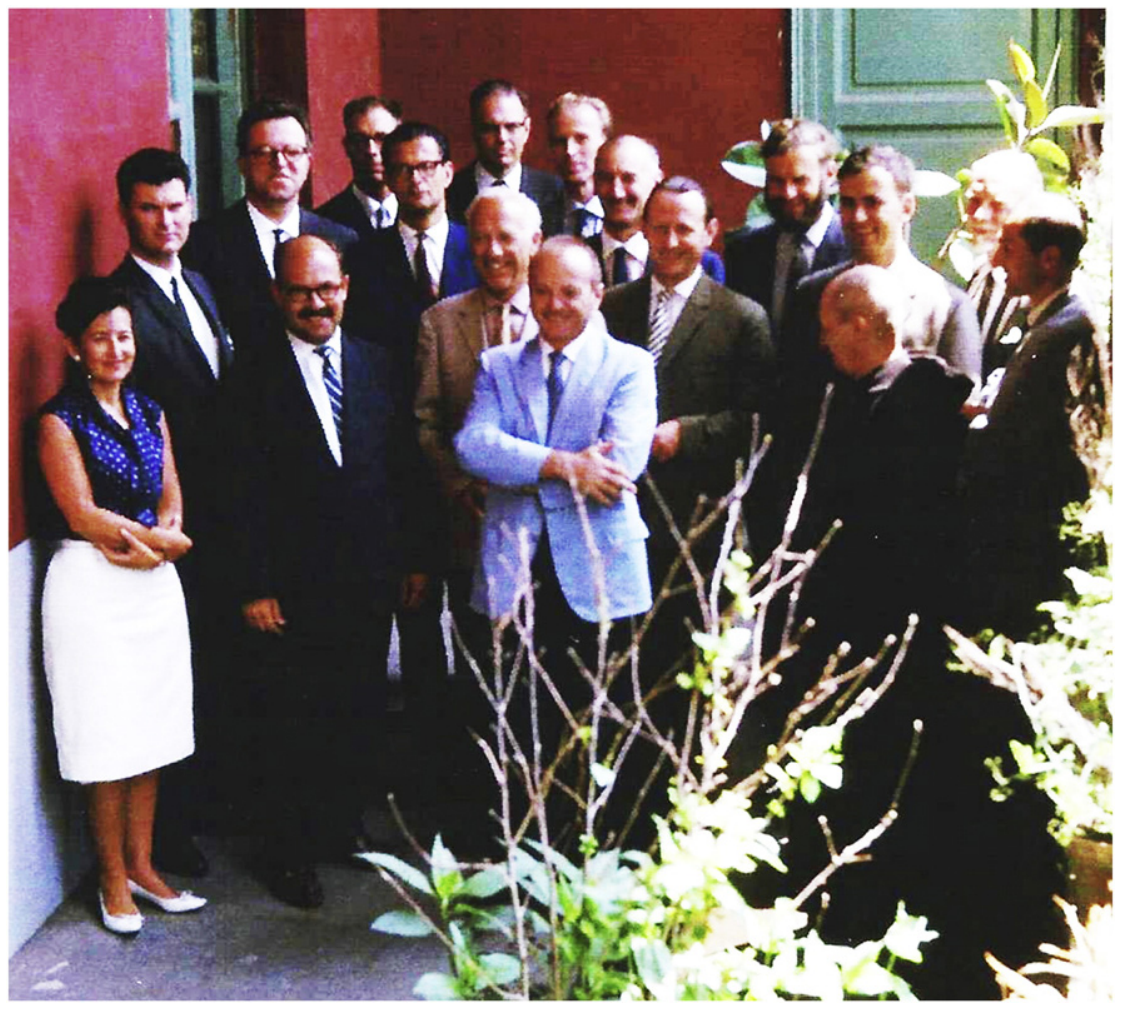

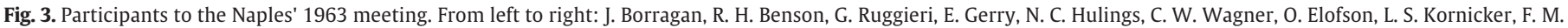
Swain, V. Pokorný, N. Grécoff, G. Hartmann, J. W. Neale, Ph. Sandberg, D. R. Rome, J. P. Hardings, K. G. McKenzie. (Credit: HJO).

first international meeting where ostracodologists from so-called "Western" countries could meet their colleagues from "behind IronCurtain" countries was held in Prague, 1968, but had to be aborted short after its beginning because of the political situation at the time.

\section{The first Period in Modern Ostracodology (from 1963 to 1983) - an enthusiastic era, well supported by the oil industry and national agencies}

The world economic situation steadily improved during the second part of the 60s, so both the national academic institutions and the oil companies invested in basic and applied research. From the 1960s onward, geological sciences were jolted by a scientific revolution with the concept of plate tectonics, explaining the geodynamics of continents and the ocean floor (Bullard, 1975). The consequences of the continental drift process for the evolution of marine fauna were extraordinarily stimulating and it reactivated ancient topics. The uniformitarian Lyellian vision was challenged by unique environmental perturbations, socalled "earth catastrophies". Two symposia were organised during the 1970s at the Woods Hole Oceanographic Institution (Berggren and Van Couvering, 1984) for a discussion of this topic. Ostracodologists were represented by R. H. Benson with philosophical and empirical arguments for the importance for earth's life of "sudden catastrophic" events, known also under the term "biotic crises" (Benson, 1984a, 1984b). During the 1960s-1970s, it became clear that the Earth experienced cyclic climatic changes which left their imprint on biological evolution (Fischer, 1981) Also important is the strong development of population ecology and the micropalaeontology, in general, with the installation of laboratories where the study of Foraminifera and Ostracoda played a pivotal role. A corollary to this trend was the development of meiofauna research in both marine and limnic domains by ecologists and zoologists. N.C. Hulings, a participant at the Naples symposium, edited for the Smithsonian Institution a manual for meiofaunal studies (Hulings and Gray, 1971). During this period, micropalaeontologists profited from the financial support of the oil exploration companies, where for accurate stratigraphic information data were offered inter alia by ostracodologists. Additionally, during the 1960s and the 1970s, American agencies had oceanographic expeditions to drill deep into the seafloor. A consortium of institutions under the acronym JOIDES (Joint Oceanographic Institutions Deep Earth Sampling) planned and operated the Deep See Drilling Project (DSDP), sponsored by the National Science Foundation (Hsü, 1983). Ostracodologists from various institutions participated in the study of material obtained by the drilling ship Glomar Challenger.

Limnology departments also expanded and limnological research flourished after 1960, especially because of the degradation of the water quality of lakes. Ostracods were used as valuable environmental indicators for the reconstruction of the dynamics of various ecological parameters. In 1964 the International Biological Programme (IBP) was initiated, funded partly by the national agencies of the OECD (Organization for Economic Co-Operation and Development) from North America and Europe. The main aim of the multidisciplinary project was the documentation of the eutrophication process in lakes.

\subsection{Favourable social spaces for scientific activities of ostracodologists}

A social space (or narrative space), as defined above, is the environment where researchers live and work (Eldredge and Grene, 1992). As a general comment, we have to say that at the beginning of the 1960s the number of doctoral and post-doctoral students dealing with ostracods in micropalaeontological laboratories was relatively low. At the Department of Geology, University of Hull, Professor J. W. Neale supervised five doctoral students (T. I. Kilenyi, P. Kaye, C. W. Haskins, R.C. Whatley, A. Lord) and a marine geologist R. V. Dingle also studied ostracods. J. W. Neale was a complete naturalist who studied and published on both fossil and living ostracods from marine and freshwater environments (Lord and Horne, 2007). In the Department of Geology, University of Leicester, Professor P. C. Sylvester-Bradley offered through his discussions with his students (R. H. Bate and later M. C. Keen, Q. Sidiqui, N. Doruk, A. Al-Furaih, J. Athersuch, David J. Siveter) and/or visitors a brilliant 
intellectual atmosphere (Benson, 1982a; DJS(C) in Sd). At the Institut de Géologie du Bassin d'Aquitaine (IGBA - affiliated to the University of Bordeaux at Talence), ostracodology developed under the leadership of Professor J. Moyes and O. Ducasse. The first students who graduated were I. Yassini (IY in Sd), P. Carbonel (PC in Sd) and J.-P. Peypouquet.

The period we analyse was propitious for students to find employment either within academic institutions or with oil companies. For instance, Yassini moved after completion of his thesis to an oil company in Iran and later to an Algerian one (IY in Sd) while other ostracodologists profited from opportunities offered by the open positions in university geology departments. A. Lord moved to University College London, while others remained within the department where they started their ostracod research, so is the case of David J. Siveter, who started with P. C. Sylvester-Bradley in Leicester.

Another pleasant aspect that made the social space of such laboratories like in Hull and/or Talence was the visits and/or the longer stay of workers from abroad. As an example, in Hull the long stay of R. L. Kaesler from the University of Kansas initiated fruitful communication and long friendship with R. Whatley, who later moved to the University College of Wales in Aberystwyth. The visits of R. H. Benson to the Micropalaeontology Department of the University of Bordeaux in Talence and the University of Leicester opened up work with J.-P. Peypouquet and P. C. Sylvester-Bradley on deep-sea and Mediterranean 'salinity crisis' material. The atmosphere was the same in some industrial laboratories. At the S.N.P.A. (Société Nationale des Pétroles d'Aquitaine, later Elf-Aquitaine), H. J. Oertli offered a friendly and also fruitful scientific atmosphere to visitors ( $\mathrm{HJO}$ in $\mathrm{Sd}$ ).

\subsection{The importance of the ISO meetings for development of IRGO as a social} system

The ostracod symposia had an extraordinary impact for the development of scientific cooperation based on friendly relationships. We start with the second ISO organised by J. W. Neale at Hull, 1967. Forty-five delegates attended and 29 contributions were published (Neale, 1969). Of the ostracodologists encountered at the Naples symposium, $50 \%$ were also present in Hull. Additionally, other well-known specialists like H.V. Howe, W.A. van den Bold, S. A. Levinson, J. E. Robinson, T. Petkovski, F. Adamczak, were present. The most important aspect was the high number of younger ostracodologists attending, like C. W. Haskins, T. I. Kilenyi, R. L. Kaesler, D. R. Wall, R. C. Whatley, A. Lord, M-C. Guillaume and others.

Some of the topics which will become persistent themes over time, were presented for the first time at Hull, e.g. the preliminary report of R. H. Benson on abyssal ostracods (Benson, 1969) or the research of R. L. Kaesler on numerical taxonomy applied to marine ostracods (Kaesler, 1969). It was in Hull that the tradition of field excursions commenced, a tradition that has continued to the present day.

The third ISO was organised by Oertli in Pau in 1970. The number of participants doubled as compared to those who attended the ISO-2 in Hull (Oertli, 1971). Again, an important percentage of the participants were young specialists, students of J. W. Neale, P. C. Sylvester-Bradley, J. Moyes, etc., with a high number of attendants from Germany, U.S.A. and of course from France. Here, we met for the first time in ISOhistory other established ostracod specialists like G. Becker, and A. Martinsson. Scientifically, the Pau colloquium brought new information on deep-sea ostracods and the palaeooceanographic history of Tethys (Benson and Sylvester-Bradley, 1971). Numerical classification was again a topic with two contributions (Jacobzone and Carbonnel, 1971; Kaesler and Taylor, 1971).

In Pau, ostracodologists were invited to participate in a geological excursion, to collect fauna and to see a famous stratotype, that of the Aquitanian. Finally, in Pau there was sufficient time for discussions, as in Naples and Hull. The feeling of the participants for the degree of friendship within the ostracodologist community was obvious. This feeling was to become stronger and contagious during the next ISOs (see also the last section of this report).

From the fifth ISO (hold in Hamburg in 1974, Hartmann, 1976), we highlight the communications dealing with the application of multivariate statistics and different algorithms for discrimination and classification of valves and limbs (Kaesler and Lohmann, 1976; Maddocks, 1976). Later on at ISO-7 in Belgrade, 1979, R. L. Kaesler and R. F. Maddocks presented a communication on the harmonic analysis of outlines of macrocypridid valves (Kaesler and Maddocks, 1987). This continuity of research with subsequent presentations at various ISOs by Kaesler stems from the interest and desire of this charismatic scientist to popularize within the ostracod community quantitative methods in ecology and morphology, which were at the time seldom used by ostracodologists, a notable exception was R. A. Reyment who published during the 1960s a series of papers using multivariate statistics (e.g. Reyment, 1963).

The 6th ISO, held in Saalfelden in 1976, is important because it was there that the Committee on Recent Ostracoda changed its name to International Research Group on Ostracoda (IRGO), and within this group a subgroup, formed by specialists of Palaeozoic ostracods, decided to have their own network that they called IRGPO (International Research Group on Palaeozoic Ostracods). In addition to their communication session integrated in the ISO, Palaeozoic ostracod specialists intended to have their own field excursions and were attracted by the idea of revising the Palaeozoic ostracods parts in R. C. Moore's, 1961 "Treatise on Invertebrate Paleontology" [DJS(C) in Sd; HGU in Sd].

The new IRGO endorsed an organisational structure. Besides having a chairman (chairwoman) a vice-chair, a secretary and a treasurer, there were members of the committee, who were voted by the ISO delegates who attended the business meeting. In Saalfelden, it was stated that the two major aims of IRGO were to support the advancement of knowledge related to Ostracoda and to facilitate communication amongst researchers.

Another positive aspect of IRGO was to officially invite colleagues from countries with constraining politics and travel bans to come to ISOmeetings. It was P. C. Sylvester-Bradley who suggested at Saalfelden-ISO to have the next meeting in a "communist" country in order to meet colleagues from the Soviet Union and P. R. China. Thus at ISO-7, 1979, in Belgrade, a Soviet delegation represented by 12 persons participated following the invitation of organiser N. Krstić. The next success was the arrival of a large delegation of Chinese colleagues at the Houston meeting (ISO-8, 1981) due to the efforts of organiser R. F. Maddocks.

\subsection{Research projects with cultural dimension}

Below, we show that a series of ostracod research projects, developed during the first period, had relevance for a wider spectrum of the educated public. For such projects, ostracodologists were able to develop their creative work and/or ideas within favourable environmental conditions. From here emerges a cultural dimension for these projects.

\subsubsection{The evidence of continental drift between Africa and South America as documented by ostracods}

During the 1960s, the stratigraphic and biogeographic studies in Brazil by K. Krömmelbein (Krömmelbein, 1965, 1966a) and those of French specialists, on ostracods of the western coast of Africa and in Africa (Grékoff, 1957; Grosdidier, 1967), documented an extraordinary concordance of Lower Cretaceous non-marine ostracods between the eastern coast of Brazil and the western counter-part of Africa (Krömmelbein, 1966b; Poropat and Colin, 2012; JPC in Sd). K. Krömmelbein identified ostracods for the Brazilian oil company Petrobras and the American Gulf Oil Corporation, and N. Grékoff worked for the Institut Français du Pétrole. After comparing their material, the two specialists published together on the ostracod faunas from the African Cocobeach Series (Gabon) and the Brazilian Bahia Series (Grékoff and Krömmelbein, 1967). Their results clearly documented the existence of Pre-Salt 
Lakes on a single super-continent, Gondwana, which were invaded later by marine ostracods (Krömmelbein, 1967). A clear image of the breakup of Gondwana and the emergent continental drift which slowly isolated Africa from South America became apparent. This information was further incorporated in introductory texts for palaeontology courses at universities (Thenius, 1976) and in books intended for educated lay people (Thenius, 1977). It should be noted that the two specialists mentioned above, belonging to different oil companies with strict rules for protection of data, found it possible to cooperate in a friendly way and offer publicly information with a cultural dimension. Additionally, new research from various ostracod experts continued to develop our knowledge on this fascinating topic (e.g. Colin and Dépêche, 1997; Bate, 1999; Do Carmo et al., 2004, 2012).

\subsubsection{The Miocene and later evolution of the Mediterranean Sea}

Ruggieri (1967) published an essay with the title we use for this section. He showed that during the last phase of the Miocene, the ProtoMediterranean experienced a drop of sea level which led to what was called "Lago Mare" with faunal elements like the mollusc Melanopsis and the ostracod Cyprideis characteristic for habitats with "reduced salinity" (Russo, 2004). This environmental scenario corresponds to what was later on called the "Messinian Salinity Crisis" (Ruggieri and Sprovieri, 1976; Benson, 2004). This geological event became part of popular science during the 1970s and the 1980s, especially through the book of K. J. Hsü "The Mediterranean was a desert” (Hsü, 1983). Here we want to stress that, during the development of the research documenting the evolution of the western Mediterranean Basin, the scientific cooperation and cultural communication between G. Ruggieri and R. H. Benson played an important role. Benson was interested in reconstructing the evolution of the deep-sea ostracod fauna and Ruggieri brought his long-year experience on the Neogene ostracods from Italy (Benson and Ruggieri, 1974). Moreover Benson, inspired also by P. C. Sylvester-Bradley, was interested to characterise psychrospheric deep-sea ostracods using morphologic criteria of the valves in order to use them for further reconstruction of the decline of the Tethys Ocean (Benson, 1979; AR in Sd). The problem of strength of valve ornamentation explained following engineering and/or architectural principles, that Benson developed was also the result of discussions and visits to historic places in Italy with Ruggieri (Benson, 2004). Another cultural aspect resulting from the friendly cooperation of these two outstanding scientists was Benson's lecture to a symposium in Venice, 1981 (Benson, 1982b), showing how morphometric techniques he developed for ostracods (cf. the Theta-Rho algorithm in Benson, 1976) can be profitably applied to the study of the Leonardo da Vinci caricatures from "Codex Urbinus Latinus". The scientific relationship between Ruggieri and Benson is an example of cooperation based on friendship for the sake of a better understanding of nature.

\subsubsection{The scientific interest of the present-day Mediterranean ostracod fauna}

From the beginning of the first symposium in Naples, the importance of detailed information on the Mediterranean ostracod fauna was stressed. At the second ISO in Hull, Puri, Bonaduce and a student of Puri presented a synthesis of ostracod distribution in the Mediterranean (Puri et al., 1969). This latter synthesis was important for palaeontologists who had in this way the data to understand the faunal changes from the Miocene to the present day (Benson and Sylvester-Bradley, 1971). Also, zoologists were interested to compare the Mediterranean fauna with the peri-Mediterranean one, like those of the Red Sea, the Atlantic Ocean or the Black Sea. Therefore faunistic studies with description of new species were continued during the 1970s and the 1980s by G. Bonaduce with various colleagues, like M. Masoli, G. Ciampo, N. Pugliese, P. Mascellaro, B. Ciliberto, G. Minichelli, J. Athersuch (Bonaduce et al., 1975, 1982; Athersuch and Bonaduce, 1976; Barbeito-Gonzàlez, 1971). Later on, Bonaduce contributed to joint- work with his colleagues G. Ruggieri and A. Russo on Neogene and/ or Holocene ostracods of the Mediterranean (Bonaduce and Russo, 1984; Bonaduce et al., 1988). The capacity of G. Bonaduce to motivate young students in their ostracod studies and also his facility to cooperate with older colleagues represent a socio-cultural quality that could be taken nowadays as an example (NP in Sd).

\subsubsection{Non-marine ostracods as (palaeo)ecological indicators for changes of environmental parameters}

D. L. Delorme during the end of the 1960s showed how the distribution of ostracods is dependent on the water chemistry of their environment (Delorme, 1969). H. Löffler using sediment samples from lakes noticed that Cytherissa lacustris was a species which, in alpine lakes of Europe, became extinct because of the increase of organic loading of lake sediments (Löffler, 1969). Later on, Löffler systematically investigated within a palaeolimnologic framework the relationship between the organic load and/or oxygen concentration of lake bottoms and the distribution of the benthic ostracod fauna. This information was offered to a wide spectrum of aquatic ecologists making ostracods popular as indicators for palaeoecologic reconstructions (Löffler, 1975; Carbonel et al., 1988).

\section{The second Period in Modern Ostracodology (from 1983 to 2003) - a period oriented more towards environmental aspects}

For the 40th anniversary of the journal "Palaeogeography, Palaeoclimatology and Palaeoecology", the editors (Bottjer et al., 2006) wrote an editorial named "Exploring life and environments through time". This title could well be adopted for the period we analyse below and where a visible trend towards more intensive ecological research related to environmental policies was done using ostracods. One should also remember that during the last part of the 20th century a strong movement developed for environmental protection. For instance, in 1988, the United Nations within its Environmental Program (UNEP) launched the Inter-governmental Panel on Climate Change (IPCC) and the trend continued in 1992 with the Rio Convention for Biological Diversity (CBD) protection, agreed by 192 countries. There was also the 1997 Kyoto protocol for climate protection against the global warming trend. The political and material support for ecological research on both climate evolution and biological diversity became better integrated into national and international policies. This became visible in Europe once a common framework for research politics was decided at the level of the European Union.

(Palaeo)ecological research during this period was embraced by a new generation of ostracodologists who was better prepared for quantitative sampling and treatment of data, as well as for the usage of experimental methods in the field or laboratory. Frenzel and Boomer (2005), who analysed the development of research on the ecology of brackish-water ostracods, show in one of their figures (here Fig. 4) a clear increase of the number of publications for the period 1981-2000. Parallel to this situation, we note that the oil companies became less interested in ostracod research, and some research laboratories like ESSO-Rep at Bègles, France, closed and scientists were obliged to take early retirement (JPC in Sd).

\subsection{Profiles for some laboratories with strong involvement in ostracod research}

The Micropalaeontology Research Group, University College of Wales, at Aberystwyth, had during the whole period a very cosmopolitan structure. Professor R. C. Whatley attracted students from various countries, namely Argentina, Brazil, Australia, P. R. of China, amongst others. Many students completed their doctoral theses with subjects from their own country or with special topics where the experience at the Aberystwyth laboratory and especially the expertise of its director were of importance. For instance, newsletter "Cypris" No 15 for 1997 


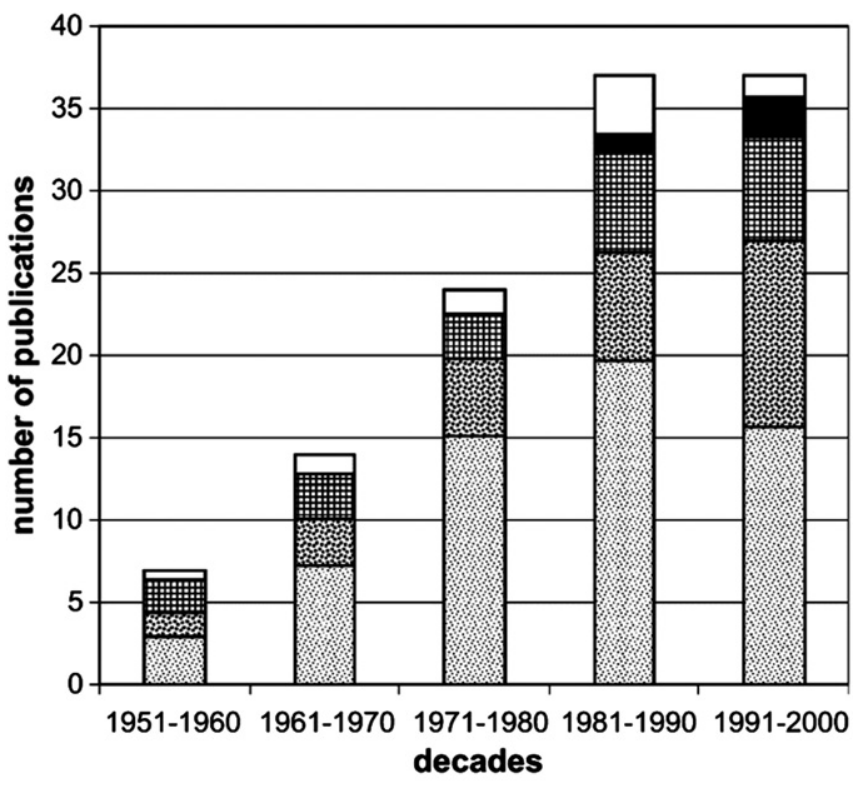

\section{$\square$ behaviour, sex ratio etc. $\quad$ geochemistry morphology 圆 assemblage quantitative : 0 assemblage qualitative}

Fig. 4. Publications on the ecology of recent ostracods from brackish waters usable for palaeoenvironmental reconstruction (1951-2000); the subdivision of bars reflects the proportion of different methods applied in these studies (from Frenzel and Boomer, 2005, Fig. 1, with permission).

reported that R. C. Whatley with his students contributed to 37 publications. The high number of South American guest students who studied in Aberystwyth is due also to the pedagogic activities of Whatley in Argentina during the 1970s and the 1980s. Several of these students started scientific and/or teaching activities in their own countries, like G. Cusminsky, an Argentinian ostracodologist who worked with Whatley, is now a university professor and leads an ostracod research group (Cusminsky et al., 2011; Coviaga et al., 2013). The same applies for Brazilian colleagues like D. Do Carmo and M.-I. Feijó Ramos, who at present are leading ostracod specialists in their country, publishing with their students or with colleagues from Europe on topics which were much discussed in Aberystwyth (Do Carmo et al., 2009; Gross et al., 2013; JPC in Sd).

In France, the most active laboratory for ostracod research was that of Geology and Oceanography, University of Bordeaux, at Talence. For the period, we discuss four full-time researchers were employed and a high number of students who prepared master or doctoral theses were active, too (PC in Sd). The social structure of the laboratory was composed mainly of francophone researchers. Those studies dealing with marine topics related to the Aquitaine Basin in the Atlantic, or in general on deep-sea were developed mainly by Peypouquet, Ducasse and their students; some of their scientific results were published in the proceedings of ISO-meetings (Peypouquet et al., 1988). Research on non-marine ostracods were mainly done by one of us (PC) with a series of students, especially related to data from projects in Europe, Africa and South America (PC in Sd).

The Zoological Institute and Museum of the University of Hamburg had, for a long period of time, as animator for ostracod research, G. Hartmann [DK $(\mathrm{H})$ in Sd]. Looking to the scientific activities of Hartmann's working group one perceives a sociological profile different from the first two laboratories. G. Hartmann, a marine biologist, travelled and sampled in many parts of the world. In his department, he had important collections of marine ostracods, additionally also those of W. Klie. In addition, there were students of ostracodology (e.g. S. P.
Jain, N. Krstić, T. Petkovski) who spent time in Hamburg to study museum material or to cooperate with assistants of Hartmann. Some of these visitors benefitted from scholarships offered by the German Alexander von Humboldt Foundation and could stay and work for longer periods in Hamburg. During his career, Hartmann was interested in the phenotype diversity of Cyprideis torosa, especially the problem of noding $[\mathrm{DK}(\mathrm{H})$ in Sd]. This topic was studied further during the 1970 s by one of his students with ecological observations from field situations (Vesper, 1975) and later on with laboratory-controlled studies by one of us (DK) and his Russian colleagues (Keyser et al., 2004). The longterm scientific interest for Cyprideis is here selected as an example of sociological translation, namely Hartmann with an important personality in ostracod research who could transmit to his students the desire to better understand one of the fascinating problems of ostracodology, the origin of valve noding. This topic, widely discussed in many publications, was partly elucidated through long-term studies done at the Hamburg laboratory. It is nowadays continued by P. Frenzel, A. Pint and their colleagues (Frenzel et al., 2012) and a whole workshop on the Cyprideis problem was convened during ISO-17 in Rome, 2013 by P. Frenzel, M. Gross and A. Pint.

\subsection{Innovative aspects of a European Research Project}

During 1994 and 1996, K. Martens led within the Human Capital and Mobility programme of the European Union a multi-disciplinary network for the project "Evolutionary Ecology of Reproductive modes in Non-marine Ostracoda". A total of 30 students coming from Belgium, Great Britain, Spain, Italy and Austria, as well as exceptionally several colleagues from countries not directly associated with the EU, participated to this project (Martens, 1998; KM in Sd). The innovative aspects of the project were first the way the topic was developed in the various laboratories, namely there were senior researchers who, in their laboratories, offered to young students the know-how to work on special aspects of the project. For instance, in the Department of Ecology of the U.A.M. (Universidad Autonoma de Madrid) as well as at the Limnological Institute of the Austrian Academy of Sciences, in Mondsee, students concentrated on ecological, experimental and/or field aspects, of various populations of two ostracod species chosen as models for this topic of research, in order to better understand the differences between parthenogenetic and sexual populations. The problems of genetic diversity between the chosen populations were examined in laboratories of the universities of Parma and Leeds as well as the Royal Belgian Institute of Natural Sciences in Brussels. Aspects dealing with the geographical distribution of living and fossil ostracods representative for this topic were investigated mainly in the Department of Geography, University of Hull and University of Greenwich, in Chatham. Thus, firstly students rotated between laboratories and were able to learn new techniques and to discuss problems with more experienced ostracodologists. Secondly, it was a unique opportunity for those young scientists to become acquainted with cultural traditions of the countries they visited. From this unique experience came first a series of scientific innovations. One of them was the building of a GIS database for Non-marine Ostracod Distribution in Europe called NODE, that contained not only the location of the various species but also additional ecological information (Horne et al., 1998). This database was not a concurrence for the Cologne Database of Kempf but a new approach that will be extremely useful during the next period of ostracod research. Other developments during this project included the improvement of videometry-techniques for observation of ostracod behaviour. The scientific output was huge, with senior scientists co-authoring contributions with small groups of the young trained ostracodologists (Martens, 1998). Finally, note that some of the young scientists who started ostracod research within this project, like G. Rossetti from the University of Parma, have now become well-established specialists of this scientific domain. 
6.3. Palaeoenvironmental reconstructions with the chemistry of ostracod valves

During the 1970s, geochemists and/or ostracodologists noted that elements like magnesium $(\mathrm{Mg})$ or strontium $(\mathrm{Sr})$ and stable isotopes of oxygen $\left(\delta^{18} \mathrm{O}\right)$ and carbon $\left(\delta^{13} \mathrm{C}\right)$ stored in the ostracod valves could provide information on the past environmental situations where ostracods lived (Cadot et al., 1972; Durazzi, 1977). Considering Mg, one of us (PDD) in cooperation with A. R. Chivas and J. M. G. Shelley started at the Australian National University (ANU) in the early 1980s a systematic analysis of the relationship between the concentration of $\mathrm{Mg}$ in ostracod valves and water temperature (PDD in the Sd). The major innovation in the ANU laboratory was to follow the evolution of $\mathrm{Mg}$ concentration in valves under controlled experimental conditions through the whole life cycle of a given ostracod species (Mytilocypris henricae) and where the post-embryonal development at various temperatures were already known (Martens, 1985). This allowed understanding of how the $\mathrm{Mg} / \mathrm{Ca}$ ratio in the valves reflects the temperature in the aquatic habitats of ostracods (Chivas et al, 1986). In parallel to these investigations, a second element, strontium ( $\mathrm{Sr}$ ), also expressed as $\mathrm{Sr} / \mathrm{Ca}$, offered information on past aquatic salinities (with some reservations as found later). This type of research was than extended to palaeoenvironment research by the ANU group, to which T. Corrège also participated. They analysed core-top and Late Quaternary samples from various parts of the world including the Coral Sea (Corrège and De Deckker, 1997) or the proto-Mediterranean domain during the "Lago Mare" event (De Deckker et al., 1999). Other research groups like those of T. M. Cronin, G.S. Dwyer and their colleagues in the US used the $\mathrm{Mg} / \mathrm{Ca}$ technique for reconstruction of palaeotemperature profiles with excellent results, especially in projects dealing with Tertiary and Quaternary palaeoenvironments in the Atlantic Ocean (Dwyer et al., 2002). Importantly, the efficiency of the $\mathrm{Mg} / \mathrm{Ca}$ approach as palaeothermometry was publicized at ISO meetings (De Deckker et al., 1999).

Stable isotopes $\delta^{18} \mathrm{O}$ and $\delta^{13} \mathrm{C}$ were successfully used during this period especially for the reconstruction of Quaternary climate. In Europe, G. S. Lister, K. Kelts and their colleagues at the ETH in Zurich and U. von Grafenstein and his group in Germany reconstructed late glacial and Holocene temperatures as well as the hydrology of deeplakes using the sediment archives from long cores (Schwalb et al., 1994; von Grafenstein, 2002). The same techniques have been applied to marine environments from the Holocene to the Tertiary (Anadón et al., 2002; Ghetti et al., 2002). One of us (LD in Sd) shows that the number of research groups in this field and their publications increased steadily during the last 20-30 years. Therefore, one should ask about the contribution of these two methodologies for reconstruction of palaeoclimate and/or palaeohydrology in both marine and nonmarine environments. First, one should note the driving force of leaders like P. De Deckker, K. Kelts, J. A. Holmes, T. Cronin, U. von Grafenstein, working in an integrative way with sedimentologists and geochemists. High-resolution sampling methods allowed data collection on centennial and/or decadal time periods (Cronin et al., 2003). Second, the protocols for the analytical work were well tested, using ostracods previously studied under experimental conditions, and/or then through well calibrated transfer functions. Some of the students involved here launched later their own projects in the same field, like K. Kelts in Switzerland and U.S.A. As an example, A. Schwalb, a former student of K. Kelts in Switzerland and the USA, now in Braunschweig, Germanny is leading projects in South America and P. R. China. Finally, another cause of success is the wide dissemination of information through journals of high impact, including the present journal of which two present and past co-editors in chief worked on ostracods (T. Corrège and P. De Deckker).

A separate direction of research was the identification in valves of trace elements like silica, phosphorus, barium using the electron microprobe (Carbonel and Farmer, 1990; Bodergat et al, 1993). The concentration of such elements in the valves offers information on the trophic status of the aquatic environment where the ostracods lived. Compared to the previous methods of environmental characterisation this latter research direction has not gained popularity, possibly because of the heterogeneity of the distribution of these chemical elements in the valves and lack of standardized protocols for analysis and interpretation.

\subsection{The deployment of ostracod research for (palaeo)oceanography and (palaeo)limnology}

For this period we examine ostracodologists who received material from major research programmes, inter alia DSDP (Deep Sea Drilling Project) and ODP (Ocean Drilling Program) to identify the ostracod assemblages and evaluate their palaeoenvironmental interest. Several groups of students worked on the deep-sea ostracods from the all the major oceans. The importance of the formation and further circulation of the water masses in these areas for the distribution of whole ostracod assemblages was recognised (Dingle and Lord, 1990; Ayress et al., 1997). Moreover, it became apparent that the SW Pacific region was the cradle of a huge biodiversity of ostracods from where fauna spread westwards during the Cenozoic (Whatley, 1990). Studies of ostracod diversity in the North Atlantic showed that the evolution of ostracod diversity had regional dimensions (Coles et al., 1990; Rodriguez-Lazáro and Cronin, 1999). It is interesting that the origin of the high deep-sea diversity in the Southern Ocean was also noted for other animal groups, like bivalve mollusks (Gray, 2001), however, without mentioning all the temporal dynamics documented by various ostracod researchers. Within the ostracodologist community the problem of the origin of species diversity represented a topic of discussion between the members of the various research teams in ISO-meetings, especially in Houston (1982), Shizuoka (1985) and Aberystwyth (1988). Angel (1990) pointed out to the importance of the local food resources for the development of rich and diverse ostracod assemblages in the deep-sea.

Peypouquet $(1975,1977)$ noted that the deep-sea Krithe species in palaeoenvironments with apparently low oxygen content displayed a wider vestibulum. Based on this observation, a whole procedure to reconstruct palaeo-oxygenation using Krithe valves was offered (Benson and Peypouquet, 1983). The approach remained undocumented by clear experimental data (Athersuch et al., 1989) and unconfirmed by other field and laboratory studies (Whatley and Zhao, 1993; Corbari, 2004). The Krithe debate merits mention here because it is an example of how an opinion, even if not very precise, still had a positive effect, namely it stimulated discussions and/or further research (Abate, et al., 1993; Coles et al., 1994; van Harten, 1995; Majoran et al., 2000; Aiello et al., 2007; Do Carmo et al., 2009). So we conclude that by adopting the liberal view proposed by the philosopher of science P. Feyerabend: "opinions are not useless" (Feyerabend, 1999).

The cooperation between R. H. Benson, with Italian colleagues, especially with G. Bonaduce, on the Messinian Salinity Crisis in the Proto-Mediterranean space, was substantiated by an important and highly cited publication (Benson et al., 1991). The problem of the ostracods of the "Lago Mare" in Italy was further studied by several Italian research groups, e.g. those of Bonaduce (Naples), of A. Bossio (Pisa) and of E. Gliozzi, (Rome) (Bossio et al., 1996; Bonaduce and Sgarrella, 1999; Aiello and Barra, 2001; Gliozzi et al., 2005).

The contribution of R. M. Forester for the correlation of ostracod distribution with water chemistry was important (De Deckker and Forester, 1988) because it prepared a new way to use the ecological distribution of ostracods for palaeoenvironmental reconstructions using either direct records or certain quantitative indices (Baltanás et al., 1990; Smith, 1993; Forester et al., 1994; Curry, 1999). P. Carbonel and co-workers further exploited this direction of research when studying non-marine ostracods from various African aquatic water bodies (Carbonel et al., 1988). Compared to the Forester approach, Carbonel 
and his colleagues from Talence included the ornamentation of ostracod valves in their analyses and further used it for palaeoenvironmental reconstructions (Peypouquet et al., 1988). Especially interesting are the field and laboratory experiments of F. Mezquita and G. Wansard for calcium uptake and magnesium and strontium partitioning in the calcite of ostracods (Mezquita et al., 1999; Wansard et al., 1999).

Another series of studies was made at the Limnological Institute in Mondsee related to the morphology and eco/geographical distribution of Limnocytherinae (Yin et al., 1999) and Candoninae (Baltanás et al, 2000; Namiotko et al., 2001). During the 1980s and 1990s, various aspects of Cytherissa lacustris were also studied, leading to the monograph "Cytherissa the Drosophila of Paleolimnology" (Danielopol et al., 1990). Finally, one should emphasize for the period discussed here on the capacity of the late J-P. Colin to cooperate with many of his colleagues and students (e.g. Cabral and Colin, 1998; Colin et al., 2000; Cabral et al., 2005).

\subsection{The International Research Group on Palaeozoic Ostracods (IRGPO)}

The group continued to meet during ISO conventions and was especially active with excursions and discussions for the preparation of the revision of Palaeozoic ostracods for the planned new version of the R. C. Moore's "Treatise on Invertebrate Paleontology" (TIPPO). For instance, during ISO-10 in Aberystwyth, several talks were offered and preceded by a lecture and discussion meeting of the Palaeozoic Treatise team organised by D. J. Siveter at Leicester and an associated three-day excursion to celebrated early Palaeozoic sections of Wales and the Welsh borderlands. The network for Palaeozoic ostracod studies, even if it was much smaller as compared to those of "postpalaeozoists", demonstrated during this time a "fraternity" with their excursions and hot debates for better communication of the ostracod data [HGU in Sd; DJS(C) in Sd].

Based on examination of publications dealing with Palaeozoic ostracods, we recognise the effort of several specialists to use the actualistic approach for a better reconstruction of the palaeobiology and the phylogenetical position of selected fossil taxa especially those already identified as belonging to Myodocopida, but also of Phosphatocopina, the Bradorida and the Leperditicopida. In various publications, J. Vannier and K. Abe (e.g. Abe and Vannier, 1995; Vannier and Abe, 1995) used as a model the living species Vargula hilgendorfii to characterise the behaviour of the cylindroleberids, the way they respire and the importance of the circulatory system. This information was then used for the reconstruction of the physiological processes of several Cambrian and/ or Silurian ostracod-groups, inter alia bradorids (Vannier et al., 1997). The extraordinary discovery of preserved limbs of Phosphatocopina (Müller, 1979) and of Bradorida (Hou et al., 1996) demonstrated their special position in the phylogenetic scheme of Crustacea (Maas and Waloszek, 2005). Their morphological and palaeobiological aspects continue to be studied by ostracodologists (Siveter, 2008). For our sociological study, it is interesting to note the importance of the cooperation of small groups of specialists (e.g. J. Vannier with K. Abe, David J. Siveter with R. Lundin, D. Waloszek and/or M. Williams). Later on, those specialists transferred their know-how to the next generation of "palaeozoists" like C. Bennett and V. Perrier (Bennett, 2008; Perrier, 2012) and the collaborative work became larger during the last 1015 years (e.g. Siveter et al, 2003; Williams et al., 2003; Perrier et al., 2013).

One of the important contributions of the IRGPO members during this period was the new way to define Ostracoda either as a monophyletic or polyphyletic group and its potential affinities with other crustacean groups. This "Fragestellung" is a thematic topic of carcinology that was discussed previously in reviews like those of Maddocks (1982) and McKenzie et al. (1983). Its re-discussion during ISO-14 in 2001 (Ikeya et al., 2005) is an excellent example of the question asked by some of us (KW in Sd) i.e. what exactly is the contribution of ostracod research to debates on major questions of natural science. At the 14th ISO at
Shizuoka in 2001 (Ikeya et al., 2005), it was clear that such questions have to be discussed via cooperation of palaeontologists with neontologists and it is not surprising that it was a naturalist like D. J. Horne who pointed out arguments for a polyphyletic structure of what we consider nowadays the taxon Ostracoda (Horne, 2005). The interest of this discussion was revitalised recently through the contributions of molecular biologists, like T. Oakley and his working group, who opt for a monophyletic structure of the Ostracoda within a pancrustacean clade called Oligostraca (Oakley et al., 2012). This way of seeing Ostracoda contrasts with the traditional approach of previous generations who perceived this class of Crustacea as divided in two sections, the Palaeozoic and the post-Palaeozoic ones. Professor G. Becker, the well-known specialist for Devonian ostracods, in his 2001 Shizuoka lecture concluded with the following view: "Truly the Ostracoda of the Palaeozoic were different from modern Ostracoda - because of evolution" (Becker, 2005). Siveter and co-workers demonstrated the existence of ostracods resembling basically the modern myodocopids already in the Silurian (Siveter et al., 2003; Siveter, 2008).

\section{The Third Period in the Modern Ostracodology (from 2003 to 2013) - activities of IRGO members within the "Global Village"}

Marshal McLuhan, a theorist for sociology of media, had foreseen as early as 1960 the development of electric (by extension electronic) technologies allowing enormous speed of the human inter-communication on a global scale. In this way, the communication of future society will resemble by analogy those of so-called "primitive villages" where inhabitants had the facility to directly inter-communicate. McLuhan coined for this utopian vision the metaphorical term "Global Village" (Coupland, 2011). The concept is now widely employed for social interaction that uses technologies like the Internet or World Wide Web by persons located widely distant (Adams, 2010). Applied to our subject this is what one of us (AS in Sd) call "the expansion of our capabilities in a new collaborative landscape".

The third period started with three international meetings, all held during 2003 and which brought together ostracodologists mainly from Europe and North America, namely the first meeting of the Italian ostracodologists "In memory of Giuliano Ruggieri", in Rimini (Gliozzi and Russo, 2004), the fifth European Ostracodologists' Meeting “Building bridges with ostracods”, in Cuenca, Spain (Rodriguez-Lázaro Ed., 2004), and the meeting at the Geological Society of America "Bridging the gap, trends in the ostracode biological and geological sciences", in Seattle, U.S.A. (Park and Smith, 2003).

The economic constraints in Europe and North America increased during this period and a reduction in the funds for scientific research where ostracodologists could be involved was very visible. Several measures were detrimental to our research domain, namely the reduction of funded projects, the downgrading of research laboratories and, related to this, a reduction of research personnel. The number of active ostracodologists in several countries shrunk drastically. If one compares the data in the Newsletter "Cypris" 2012 with those presented in "Cypris" 1997, in the U.S.A. a reduction of 75\% of active researchers took place, $77 \%$ in the U.K., $55 \%$ in Germany, only $22 \%$ in Italy, while active ostracodologists in France remained stable but in low number. These data have only an indicative value as we know that not all the IRGO members send yearly reports to "Cypris". However, the trend to a reduction of ostracodological activities and their practitioners was perceived also in other countries like Russia and China (E. Schornikov, E. Tesakova and D. Zhai, pers. comm. to DLD).

Returning to Europe and North America, we note that most of the ostracodologists work in academic institutions, like universities and museums; there are now fewer ostracodologists employed by companies dealing with oil exploration. A spectacular opposite trend exists in Brazil where for 2012 "Cypris" registered 23 ostracodologists, graduate personnel and students preparing master or doctoral theses. This represents a $70 \%$ increase as compared to the data in the newsletter 
for 1997. The situation clearly reflects the economic activities in this country where about 39\% of the registered ostracodologists are employed by oil companies. Also, the universities in Brazil continue to have an active education system where subjects dealing with ostracods are offered to students for their degree projects. More interesting is the new approach in the Micropalaeontology Department of the Institute of Geosciences at the University of Brasilia where a zoologist, R. Pinto, has been hired so that he "will improve integration between studies on fossil and Recent Ostracoda" (statement of D. A. Do Carmo, head of the institute, in "Cypris" 2013). Zoologists with a good knowledge on living ostracods can help palaeontologists in the reconstruction of phylogenetic lineages and in the understanding of habitats where ostracod species lived. As an example, the information on Microdarwinula in Brazil published by Pinto et al. (2005) helped understanding the ecological requirements of Tertiary microdarwinulids.

A widening of scientific cooperation led to a fast turnover of knowledge on Ostracoda. This is visible in books very similar in aim and domain of research, namely "Ostracoda in the Earth Sciences" (De Deckker et al., 1988), "The Ostracoda - Applications in Quaternary research" (Holmes and Chivas Eds., 2002) and the "Ostracoda as Proxies for Quaternary Climate Change" (Horne et al. Eds., 2012). The books were issued $\sim 10$ years apart and, by looking at their content, one can see the rapid growth of techniques and expertise for palaeoclimate reconstruction. Five examples which in our opinion reflect the trend for globalisation of research within wide and spatially spread networks are presented below.

\subsection{The OMEGA (Ostracod Meta-database of Environmental and Geographic Attributes)}

This is a project, discussed in 2011 at EOM-7 in Graz, which deals with the development of a meta-database for ostracod species with wide geographic distribution, some of them having an intercontinental dispersion. For such ostracod species the database contains much environmental and geographical information (Horne et al., 2011a). The initial research network was formed by students from the U.S.A. Canada, U.K., Belgium, Germany and Japan. It started from a previous European initiative, NODE, mentioned above, and into which was recently integrated information from three North American databases: NANODe (North American Ostracode Database), DOAD (an ostracod database containing autecological information and stored at the Canadian Museum of Nature in Ottawa), and NACODe (North American Combined Ostracode Database) (Curry and Smith, 2012; AS in Sd). To these databases other information from southern Africa and East Asia will be added in due course. The OMEGA meta-database should "facilitate global palaeoclimatological, paleoenvironmental and biogeographical research using ostracods" (Horne et al., 2011a).

D. J. Horne, one of the initiators of OMEGA, developed the idea of taxonomic harmonisation for the practical identification of ostracods that should be used in global monitoring schemes. It means that ostracods should be identified by clear morphological traits visible in many populations within large geographical areas. It therefore also supposes that the various populations should display approximately similar ecological and/or biological attributes. This idea represents a conceptual innovation with wide applications. Some specialists, considered as taxonomic splitters, use minimal discriminant characters for species definition. This leads to difficulties when taxa are used for ecological purposes. Sames and Horne (2012) show that taxonomic harmonisation is a useful approach for palaeoecological application even for older fossil taxa, such as those of late Mesozoic non-marine ostracods belonging to Cypridea.

\subsection{Stable isotopes and transfer functions for non-marine ostracods}

These are applications that became common tools for palaeoenvironmental reconstructions during the last 10 years. L. Decrouy shows that the number of publications dealing with stable isotopes increased especially through research in United States, Germany and China (LD Figs. 2 and 6 in Sd). Considering the researchers working in the latter two countries, we note the existence of dynamic networks based on scientific trans-regional cooperation. First, at national scale a cooperation contract between Germany and China named "Tibetan Plateau: Formation-Climate-Ecosystems" (TIP) where the German research agency, DFG, funded the so-called Priority Programme 1372. As subprojects, there are several themes of research where ostracodologists are very active; for example, the group led by A. Schwalb (Technical University Braunschweig) and that led by P. Frenzel (University of Jena) studying mainly lakes on the southern part of the Tibet Plateau, like Lake Nam Co. Another group of German scientists lead by S. Mischke (Free University Berlin, now University of Potsdam) investigates the northern part of the Tibet Plateau. In both cases, Chinese colleagues from the Chinese Academy of Sciences, the Institute of Tibetan Plateau Research (Zhu Liping, Shishang Kang and their students), from Qinghai Institute of Salt Lakes (Zhongping Lai and co-workers) as well as from other institutions like Lanzhou University (Wanyi Zhang) are partners. As examples of research projects, we mention here the impact of the dynamics of the monsoon on Lake Nam Co's water level fluctuations during the Holocene (Frenzel et al, 2010; Wrozyna et al., 2012) and the successful cooperation of the group who studied Lake Donggi Cona in Qinghai Province. A whole series of publications has been completed by S. Mischke and his German and Chinese co-workers (Mischke et al., 2008, 2010). Geoarchaeology projects where ostracods play an important role significantly developed as compared with the previous periods. Carbonel (1983) studied ostracods from the famous site Taudenni in Mali, Griffiths (1999) published on a Mesolithic site in Ireland, Mazzini and her colleagues (Mazzini et al., 2011) studied ostracods from the Roman Imperial harbours of Portus, near Roma, Lord and co-workers investigated a Neolithic site in Portugal (Lord et al., 2011)).

DecLakes (Decadal Holocene and Late-glacial variability of the oxygen isotopic composition in precipitation over Europe reconstructed from deep-lake sediments) is another trans-regional project this time at the European scale funded by the European Science Foundation in cooperation with national agencies for supporting research. Ostracodologists from France (U. von Grafenstein), Germany (N. Andersen), Poland (T. Namiotko), Spain (A. Baltanás) and Austria (D. L. Danielopol) studied the Late Glacial and Holocene ostracods of deep-lakes Mondsee (Upper Austria), Iseo (northern Italy) and Hancza in northeastern Poland during 2003-2007. Stable isotopes of oxygen and carbon of fossil ostracods were used for the palaeoclimatic reconstruction on both sides of the Alps as compared to those of northern part of Poland. The project was developed as a multidisciplinary study having also the cooperation of sedimentologists and geochemists belonging to German, French and Italian institutions (Lauterbach et al., 2011; Namiotko et al., 2013). The success of the project has to be viewed also as the product of the social life. Ostracodologists and their geologist colleagues fused in an "enlarged scientific family", where every year they met for workshops organised in one of the participant countries as well as during the field work. These places with their social life formed for a short period of time "villages of scientific life", in the sense of J. Ziman's metaphoric term (Ziman, 1984).

\subsection{The cooperation for taxonomic revision of the Eastern and Central Paratethys ostracod fauna}

This activity became a real necessity for ostracodologists after 1990 because of palaeoecologic and palaeobiogeographic interest in Western Europe, especially in Italy. Species like Loxocorniculina djafarovi Schneider (Grossi et al., 2011), known at the time from the Eastern Paratethys in northern Abkhazia (Suzin, 1956), occurs in Messinian deposits in Italy, together with a whole range of other species from Eastern and Central Paratethys. The revision of the Paratethys fauna became necessary because the original descriptions made mainly during 
1950-1960 by specialists from East and Central European countries were rather incomplete. After 1990, the possibility to visit colleagues and to work in the field in Eastern and /or Central European countries like Russia, Romania and Slovakia allowed ostracodologists from both geo-political areas to cooperate. E. Gliozzi presents her experience with the examination of ostracods from collections made by Soviet specialists like V. E. Livental (EG in Sd). Gliozzi emphasizes the extraordinary capacity for cooperation and the generosity of Russian and Romanian colleagues during her studies in Moscow, St. Petersburg and Bucharest. A multi-author publication resulted from this cooperation is proposed for the present journal and a long abstract was published for ISO-17 (Gliozzi et al, 2013). The same successful cooperation between colleagues from Central and Eastern Europe with their colleagues from Western Europe is apparent in various recent publications (e.g. Boomer et al., 2000, 2005; Danielopol et al., 2008; Krijgsman et al, 2010; Stoica et al., 2013).

\subsection{New perspectives for the research dealing with deep-sea ostracod fauna}

The success of this research direction is due to several factors. Firstly, there is a societal need for better understanding of the way climate changed in the past and what we can expect in the near future. Secondly, we note a stronger cooperation between palaeontologists and zoologists. Thirdly, established models or accepted hypotheses were re-examined by young ostracodologists with much more critical attention than done by earlier specialists. Finally, we observe that, as during the previous analysed periods, some of the national research agencies continued to fund multidisciplinary projects. For instance, research in the North Atlantic Ocean, in the sub-polar area, presented in Alvarez Zarikian (2009), Alvarez Zarikian et al. (2009) and completed within the Integrated Ocean Drilling Program (IODP), was partly funded by the Joint Oceanographic Institutions-US Science Support Program (JOI-USSSP) and by the Deutsche Forschungsgemeinschaft (DFG). Their research on ostracods (Alvarez Zarikian, 2013) confirms studies of T. M. Cronin, M. Yasuhara, G. Hunt and their colleagues (Cronin et al., 2005; Hunt et al., 2005; Yasuhara et al., 2009) who, using high resolution analysis of sediment cores, show that temperature fluctuations in the Atlantic deep-sea follow the earth's orbital variability on millennial to decadal scales. This aspect is interesting because it supersedes the traditional view of oceanic depths as thermally stable environments over long periods of time (thousands of years) and where high diversity of meiofauna developed (Gray, 2001). Moreover, looking to the research activities of Cronin and his working group we note that during this last period they were amongst the most productive investigators of the Atlantic deep-sea using a wide range of techniques for palaeoenvironmental reconstruction. Cronin was also able to transmit his know-how to young collaborators. He encouraged his co-workers to document the fossil fauna with detailed descriptions, SEM images, multivariate statistics, chemical analysis of the valves, and transfer functions for key ecological factors derived from ostracod data (Cronin et al., 2002; Yasuhara et al., 2009). For his outstanding scientific research, T. M. Cronin was awarded the 2009 Brady Medal of The Micropalaeontological Society (Horne and Lord, 2010). An interesting case of collaboration across disciplines and generations is that of the young scientists, S. Brandão, a zoologist, and I. Slipper, a palaeontologist, with a more experienced investigator, D. J. Horne (Horne et al., 2011b). Their joint contribution lead to the refutation of an accepted palaeoecologic model called the "Platycopid Signal Hypothesis" (PSH) proposed by Lethiers and Whatley (1994). First, Brandão started with observations on living specimens (Brandão, 2008), which were continued with a critical examination of the PSH model and its predictions (Brandão and Horne, 2009) and, finally, it was demonstrated that it is not the low oxygen concentration in the deep-sea that explains the abundance of platycopids but their feeding efficiency in oceanic oligotrophic habitats (Horne et al., 2011b).
Another progressive aspect in ostracod research is the application of molecular biological techniques when combined with more classic studies on morphologic traits; these allow better documentation of the high species diversity of selected ostracod lineages widespread in the deep-sea (Brandão et al., 2010). Related to this question are the evolutionary biological studies of T. Oakley and his research group on myodocopids using molecular biology and phylogenetic methods. Syme and Oakley (2012) argued for a possibility to refute Dollo's law relating to the irreversibility of morphologic traits, such as the regressed eyes of oceanic cylindroleberidids. The reversibility of morphologic traits was discussed by Dingle (2003) and Horne (2010) with arguments from fossil ostracods, but the application of molecular-biological techniques is appealing for this debate. We thus perceive progress in the study of deep-sea ostracods. In the examples we mentioned the important role of cooperation between young and more experienced researchers represents a sociological dimension involving IRGO members.

\subsection{The SexAseX project and the concept of integrative taxonomy}

This is a European Community project within the Marie Curie Research Training Networks (RTN) programme 2004-2008. The project led by one of us (KM) dealt with the study of a model ostracod species, Eucypris virens, its morphology, ecology, behaviour, genetics, molecular biology, and geographical distribution. The main interest was to better understand why this species, widespread in Europe, and now also known in Australia (as a passive introduction from Europe), is represented by sexual and asexual populations. There is also the question of why should this ostracod species switch from sexuality to parthenogenesis. Within the project experienced ostracod researchers from Belgium, the Czech Republic, Germany, Great Britain, Italy, Poland and Spain, worked together with students from different countries like Portugal, Sweden and Germany. These latter students received in a multidisciplinary environment training and transfer of knowledge existing in the host institutions (Cordis-homepage- http://cordis.europa.eu/ projects/rcn/73697_en.html and KM and IS in the Sd). As compared to the previous European project developed within the Human Capital and Mobility programme and discussed above this one integrated biologists who were specialists in other animal groups than the ostracods, or who worked on theoretical problems of evolution. This allowed wider discussion and transfer of information during courses and external workshops. The output of the project in journals with high impact factors and wide distribution is impressive (Adolffson et al., 2009; Bode et al., 2010; Schmit et al., 2013). Lead authors of these three publications were doctoral students who completed their PhD theses with material worked on during this research period. The number of coauthors is remarkable as an expression of cooperative work; Bode et al. (2010) has 12 co-authors of which five are doctoral students. Through this project we now see that widely distributed species like E. virens represent a cluster of cryptic species and that the mode of reproduction is related to specific environmental conditions.

With the experience accumulated from this project two of us (KM and IS) launched a multidisciplinary project in Australia where, beside E. virens, another ostracod group, Bennelongia, was studied applying the same conceptual approach, namely simultaneous study of morphological traits, molecular biological characterisation of populations for phylogenetic reconstructions, studies of ecological requirements and of geographical distribution. For this multidisciplinary study, specialists and students from Europe and Australia worked together again (Koenders et al., 2012; Martens et al., 2012; De Deckker and Martens, 2013).

An "integrative taxonomy" emerged for a Bennelongia phylogenetic lineage with the documentation of many new species (KM and IS in Sd). Finally, one should see in the research of K. Martens, I. Schön and their colleagues, an expression of the intellectual interconnection which developed at a transcontinental scale. It shows us that the world is getting "smaller" and easily accessible for scientists. 


\section{The quest for improved communication - perennial themes in ostracodology}

In any research domain there are subjects which are transmitted from one generation to the next, each time adapted to the momentary Zeitgeist and scientific needs. For ostracodology the communication of information took two different directions. The oldest one is the imaging of ostracods as a way of conveying the descriptive information in a more complete and exact way. Several of us [RMK, DJS(I), KW in Sd] offer detailed information on this subject which is only briefly presented here. The practical importance for ostracod communication is discussed by GM in Sd.

The other direction of communication is the dissemination of ostracod information through written and/or electronic pathways of discussion and/or transmission of data between specialists, outside the meetings like ISO, EOM or the national conferences. (RMK \& FV in Sd). The material substrate for this second direction of communication improved during the 50 years period and combined with the imaging approach forms the basis for what Latour (2005) called the nonhuman component of the Actor Network Theory. Around these communication themata, social networks with IRGO members developed as we will show below.

\subsection{Major steps in the evolution of imaging techniques for ostracods}

During the Heroic Period of Ostracodology, i.e. end of 18th and the first part of the 19th century, ostracods were illustrated, sometimes with imaginary details (RMK in Sd). The exact illustration of ostracods in the monograph of G.W. Müller (1894) represented a historic event which attracted many specialists to the Biological Station in Naples, as previously discussed. It was the practical necessity for improved illustration of ostracods that determined ostracod specialists during the mid 20th century to develop photographic techniques related to LM (light microscopy). E. Triebel during 1940-1960 achieved an extraordinary photographic precision with his illustrations for both ostracod valves and limbs (Triebel, 1968; RMK in Sd). Some of us noticed that the Triebel illustrations for type material deposed in the collection of Senckenberg Museum were more useful and informative as compared to the original material too delicate to be displaced or examined in foreign laboratories. Similarly, the seminal cytological work by Rome (1947) provided exceptional observations an outstanding illustrations of the anatomy and nervous system of a single freshwater ostracod Herpetocypris reptans. As many curators have similar problems, namely a reluctance to send out precious material from collections, one of us (GM in Sd) proposes general adoption to develop an efficient photographic documentation and to offer illustrations to ostracodologists interested in museum material, instead of loaning valuable and delicate ostracod material. This latter project can be successful only with social consensus within our scientific community, that ostracodologists and museum curators communicate in a co-active way in order to get the exact information required.

The next breakthrough in the illustration of ostracods was facilitated by electron microscopy. For the first time the Scanning Electron Microscope (SEM) provided for detailed surface views of valves greatly improved the documentation of fossil ostracods. Sandberg and Hay (1967), followed by P. A. Sandberg alone and by P. C. SylvesterBradley, offered information on this new technique, showing especially the importance of combining the SEM technique with stereoscopic procedures. Finally, it was Sylvester-Bradley (1973) who produced the practical change in imaging ostracods with SEM when he launched the series A Stereo-Atlas of Ostracod Shells that he edited from the beginning with his then postdoctoral research assistant David J. Siveter. The introductory essay had a suggestive title: The New Palaeontography (Sylvester-Bradley, 1973). During the next 20 years about 700 species were published with SEM stereoscopic microphotographs [DJS(I) in Sd] and the application of the SEM to ostracod visualisation became the standard method in the taxonomic description, especially for palaeontological purposes. It appears now (but see also Benson, 1982a) that Sylvester-Bradley with his Stereo-Atlas project produced what one could call a scientific revolution in ostracod description. For the purposes of this review it is important to stress the sociological aspect of the SEM imaging. Those who were lucky to have a SEM in their institutions were always generous to help their IRGO colleagues. $\mathrm{H}$. J. Oertli, D. Keyser, I. Slipper and D. J. Horne helped many times their colleagues who had not benefitted from this facility. The enthusiastic support of the various teams of editors for the success of A Stereo-Atlas of Ostracod Shells is one of the sociological aspects of IRGO.

Another imaging revolution was the discovery of Palaeozoic bivalved arthropods looking like ostracods and which being incrusted and impregnated with calcium phosphate allowed the preservation not only of valves but also of the limbs still existing into the carapace. It is the achievement of K. J. Müller (University of Bonn) to have developed an efficient technique to recover phosphatocopid specimens from Cambrian and other Palaeozoic sediments, of what are called phosphatocopids, with limbs that in many cases were surprisingly well preserved (Müller, 1964). Later, Hou et al. (1996, 2010) demonstrated that (Cambrian) bradoriids had an anatomy different to those of Ostracoda. Even if we know now that these two groups belong phylogenetically outside the Eucrustacea, the ostracodological approach helped enormously to build a new picture of the early diversification of proto-crustacean groups which lead to Ostracoda (Walossek, 1999). This information was transmitted to ostracodologists during various ISO and EOM meetings (Müller, 1979; Maas and Waloszek, 2005; Siveter, 2008). The revolutionary approach of Müller allowed recovery of phosphatised fossil ostracods with limbs from Late Palaeozoic strata, Devonian (Olempska et al., 2012) and post-Palaeozoic deposits, (Bate, 1972; Smith, 2000; Williams et al., 2008; Matzke-Karasz et al., 2013). Here again IRGO-members (palaeontologists and neoontologists) cooperated in networks for description and interpretation of their material.

The most recent developments in imaging ostracods have produced the next scientific revolution. Siveter et al. (2003) reconstructed with virtual images the limbs of a Palaeozoic (Lower Silurian) myodocope ostracod. R. Matzke-Karasz and co-workers used X-ray synchrotron tomography for evidetiation of petrified sperm of non-marine ostracods of Cretaceous and Early Miocene (Matzke-Karasz et al., 2009, 2014). Other ostracodologists could obtain images of mummified spermatozoids in Early Pleistocene ostracods using scanning confocal microscopy (lepure et al., 2012). Again, as with the phosphatised fossils of K. J. Müller and his colleagues, the new images and structural reconstructions needed interpretation and offered a chance for scientific cooperative work in order to make palaeobiological or palaeoecological reconstructions (Williams et al., 2011; DJS(I); RMK in Sd).

Another imaging development was the representation of ostracod valves using a synthetic pictorial format with an explicit nomenclature of the surface structures (Sylvester-Bradley and Benson, 1971). This simplification of ostracod representation helped communication of descriptive data. The approach led in some ways to the next breakthrough in the imaging of ostracod valves namely the usage of geometric morphometrics and multivariate statistical methods for recognition of morphological traits (Baltanás et al., 2003). Considering these latter techniques R. H. Benson, R. L. Kaesler, R. Reyment and A. Baltanás contributed substantially during the last 40-50 years to the development of various algorithms (Baltanás and Danielopol, 2011). Interestingly, some old techniques useful for imaging ostracods, like the argentophilic staining of tissues developed by Demal and Rome (1953) should become in the future more popular (KW in $\mathrm{Sd}$ ).

\subsection{Gradual changes with the dissemination of ostracod information}

IRGO colleagues, since already Naples Symposium, 1963, considered the necessity to better convey ostracod information to specialists active 
within other scientific directions or directly to laymen. The first step for effective communication outside the ostracod meetings was the production of a newsletter for which E. Gerry was the mastermind for 20 years. With enormous enthusiasm, he collected information all around the world and produced the quarterly newsletter named "The Ostracodologist". The editorial activities of the newsletter which were based in Israel moved in 1983 to the United States where E. Brouwers took in her hands the destiny of what we know now as the "Cypris" newsletter. The last issues were produced in cooperation with one of us (FV) at the University of Cologne. Both newsletters were of invaluable help to IRGO ostracodologists offering bibliographic information, addresses of colleagues and brief information of scientific activities.

The next innovation of IRGO was the implementation in 1995 by R. F. Maddocks on the University of Houston server of an electronic discussion-platform named OSTRACON. About 300 ostracodologists are nowadays registered. A wide range of information circulates through OSTRACON, especially requests for bibliographic data or reciprocal information on techniques or other matters (e.g. a recent discussion was about how and/or who could translate several specialised ostracod terms from Russian into English or French). In this way, "Cypris" and OSTRACON are two important factors which contributed to the social cohesion of our ostracodologist community. The current use of the English language as lingua franca for scientific communication helps the dissemination of knowledge. As an example the doctoral thesis of H. Uffenorde written in German (Uffenorde, 1972) is only quoted twice by Google Scholar (information from 30.02.2013) while the same work published in English (Uffenorde, 1975) is listed 43 times!

An important achievement for our community is the Kempf Database Ostracoda (KDO) based at the University of Cologne (Kempf, 1980-2013). This invaluable stock of information of about 300,000 data entries, presented in the form of books and CDs as well as a library of about 20,000 publications, is a wonderful resource and attracts constant consultation. From 1974 until now, the databank was developed and managed by one person, Professor E. Kempf. The Society of Friends of IRGO has initiated an action to develop around the KDO an Ostracod Information Service Centre with permanent personnel around the KDO.

Another aspect of dissemination of ostracod data that has an impact on the social aspects of IRGO members is the cooperative production of books with a special topic or aim. For a long period, ostracodologists used as an introductory text van Morkhoven's book "Post-Palaeozoic Ostracoda, their morphology, taxonomy and economic use" (van Morkhoven, 1962) in combination with the 'Ostracoda' volume Q of the American Treatise of Invertebrate Paleontology (Moore, 1961). The two volumes by van Morkhoven (1962) used much information from E. Triebel's long ostracod experience as well as Kesling's (1951) superb illustrations and his study of ostracod ontogeny. Before that, there was also the seminal volume the Fauna of the USSR produced by Bronstein (1947; translated into English in 1988), but only dealing with freshwater ostracods. Parallel to this monograph was the important monograph by Elofson on the ecology of marine ostracoda from Sweden (Elofson, 1941; translated into English in 1969). During the 1980 s, it became necessary to offer books on progress made in ostracodology during the contemporary period. Therefore, van den Bold (1974) edited a volume in the memory of the ostracodologist Henry V. Howe on many new aspects of ostracods. Further, De Deckker, Colin and Peypouquet edited "Ostracoda in the Earth Sciences" (De Deckker et al., 1988) in which 15 colleagues offered a wide range of ostracod information that is still very helpful for present-day workers. One should mention also the cooperative effort for the production of synoptic books necessary for identification of ostracods, like "A stratigraphic index of British Ostracoda" (Bate and Robinson, 1978), the "Atlas des Ostracodes de France" (Oertli, 1985), the guide-book "Marine and brackish water ostracods" (McKenzie et al., 1989) and the "Ostracods in British stratigraphy" (Whittaker and Hart, 2009). These books play an important role for the routine identification of ostracod material. Looking to the list of contributors in these books we recognise immediately the friendly relationships which existed at the time between the various specialists and which certainly helped the cohesion of the projects. HJO remembering the French ostracod atlas stressed the immense satisfaction the authors had once they saw the completion of their project. And the same feeling of friendship and satisfaction probably existed also for the teams of the other books.

Another effort of ostracodologists was to integrate their research within a wider spectrum of topics. In 1970, P. C. Sylvester-Bradley proposed the transformation of the International Palaeontological Union into a functioning International Palaeontological Association (IPA) to which 14 research groups were affiliated. Three of them dealt with ostracods (Teichert and Yochelson, 1985). M. J. Copeland was in charge for research group Palaeozoic Ostracoda, R. H. Whatley for Postpalaeozoic ones and A. Sokač for Neogene ostracods. This decision represents an important initiative towards the integration of ostracod research within a broader scientific landscape. Several years later, K. G. McKenzie initiated the series of symposia named "Shallow Tethys". Shallow marine and freshwater ostracods of Tethys formed a special research group which discussed their data during four Tethys-symposia and within a broader audience of palaeontologists dealing with other fossil groups (McKenzie, 1978, 1987). Here we mention an example of the way ostracodologists were able to translate their knowledge to a wider spectrum of specialists. With the same line of thought, Schön et al. (2009) edited a multi-author book dealing with the problem of the evolutionary biology of parthenogenesis. The experience obtained from the two European research projects (NODE, SexAseX) were integrated and further discussed within the broad spectrum of topics presented by a wide range of specialists.

\section{Final thoughts: IRGO, the "great ostracodologist family"}

H. J. Oertli expressed the idea that members of IRGO through their good relationships could be considered "a big family" (HJO in Sd). Social networks viewed as a metaphorical family was discussed by Koch (2005). Social systems maintain their internal coherence and implicitly their existence through communication between participants and are able to perpetuate from one generation to the other. This is exactly what we showed in this report, that IRGO developed its own dynamics of communication within a clear organisational structure. The same applies with EOM, the European Ostracodologist Meetings and further with the national or more local meetings like the ostracod activities of the TMS (The Micropalaeontological Society) in the U. K., or ROLF (Réunion des Ostracodologistes de Langue Française) related more to francophone specialists or the IGOM (International German Ostracodologists Meeting), initially developed for German speaking ostracodologists, and so on. But more important are the lively communications during official meetings like the ISO-s (RMK \& FV in Sd; AL in Sd). The last conventions had around 100-130 participants from many countries (Fig. 5).

We have noted for the 50 years period and the ISO meetings a clear turnover of three generations of ostracodologists. During the ISO-17 in Rome, we perceived the arrival of the fourth generation of ostracod practitioners, and enthusiastic researchers (www.irgo.ostracoda.net). This image of IRGO appears more optimistic than the idea of a shrinking ostracodological community as mentioned in OSTRACON during 2012. It is also interesting to observe the sociological profile of this community, namely it remained largely closed during the ISO-meetings, most of the participants were ostracodologists. Hence some of us (AB, AL during ISO-14, Chatham, KW in the Sd) wish(ed) to encourage broadening of the social profile following the pioneering ideas of P. C. SylvesterBradley mentioned above.

Outside the IRGO social network one notes that many ostracodologists work(ed) within multidisciplinary groups and in this way they are integrated in a sort of "invisible college". It would be profitable to have participants within IRGO who are not necessarily highly specialised ostracodologists. The cooperation between De Deckker and 


\section{Distribution of ISO Attendees}

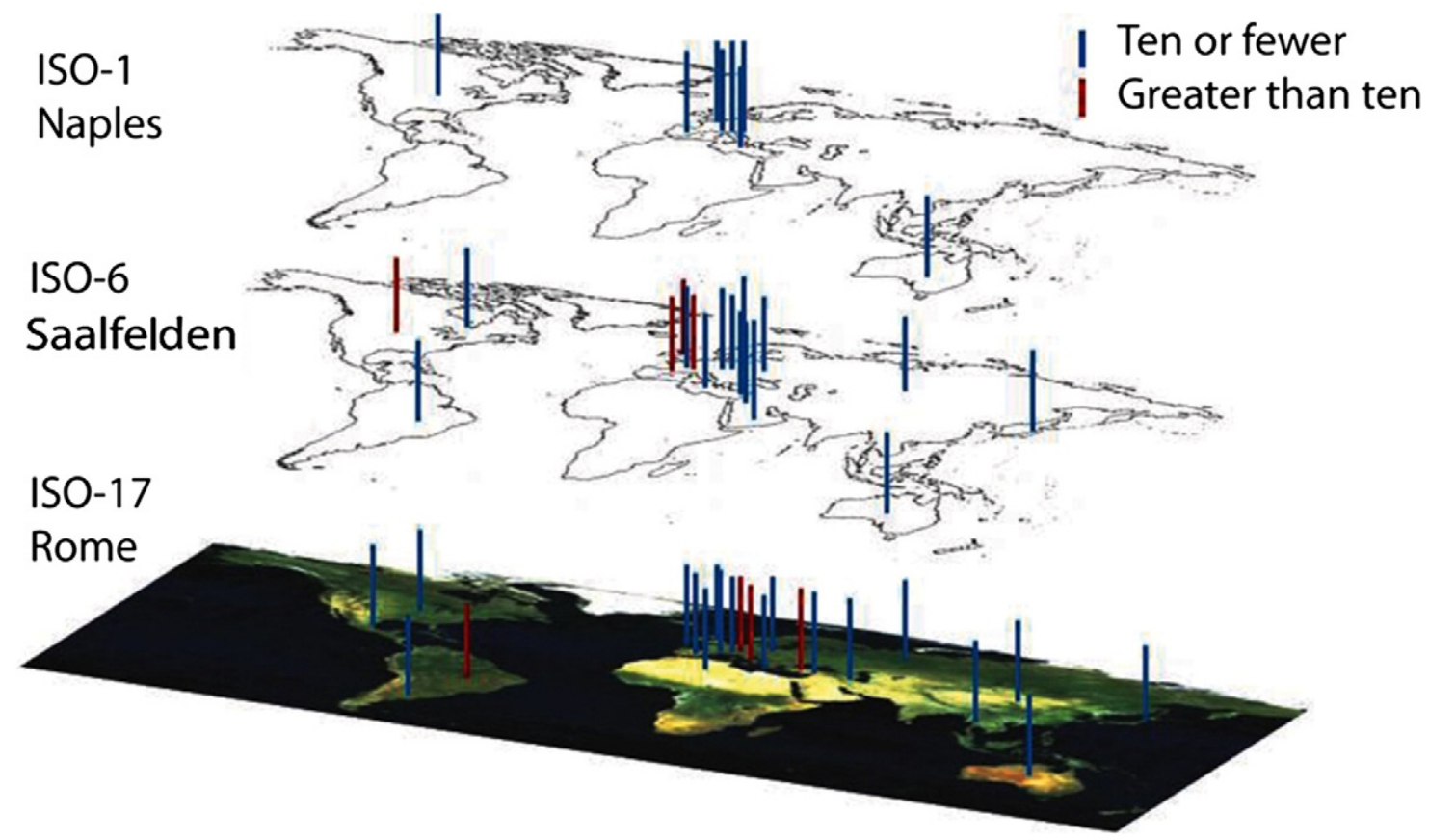

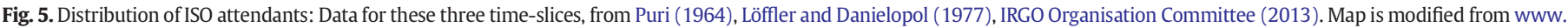
esa.net. (Credit: AS)

his colleague Chivas (PDD in Sd) is an excellent model for the necessity of opening our communication network with non-ostracodologists.

During the development of this project several of us (EG, DJS, SC) suggested that our report should represent a helpful message to the young generation of ostracod researchers. D. L. Hull in his book "Science as a process" notes the smallest unit in science is the individual researcher, who has to develop his or her personality (Hull, 1988). The importance of working within creative teams represents the best chance for young scientists to develop their scientific profile which can further lead to new career opportunities. Several of the co-authors of this report mentioned the importance of strong personalities who played a role during their research activities. Sylvester-Bradley, Neale, Lethiers, Grékoff, Hartmann, Puri, Ruggieri, Bonaduce and Benson were mentioned by NP, AR, DJS, AL, SC, JPC, in Sd. These exemplary personalities could attract the interest of young ostracodologists now. This is precisely what the recipient of the Sylvester-Bradley Award for the best communication of a young scientist participant to the ISO-17 in Rome, July 2013 told to one of us (DLD).

Related to the centres of excellence mentioned above, we should remember the contributions of personalities who invest(ed) their energy for the maintenance of good working facilities in their laboratories. Although in recent years departments, laboratories and/or working groups became reduced, nevertheless, during the same period one notices that other successful working groups are emerging, some of them within a consortium of laboratories. The merits is not only of researchers but also to the leaders of these research groups, persons who devote time to apply for grants, to present results to various meetings and who support efficiently their students. This managerial activity is an important sociological aspect, sometimes a real art of the persons involved that should be recognised and if possible adopted by newer workers in preparation for the future.

It is also important to recognise a pattern of cyclicity over time for the interest on ostracod research. For instance, the exploration of fossil ostracods in caves, a subject pioneered by Gliozzi and Mazzini (1998) is now a subject dealt with by ostracodologists within a new perspective (Matzke-Karasz et al, 2013; SI in Sd); all this is a proof of the force of a new generation of ostracodologists to continue ideas of older colleagues.

Collections of ostracods well stored and curated in museums, which others can use for their studies, appear as an important component of the "social game" presented here. Globally, there are many important collections of ostracods, for example in London (Natural History Museum), Washington (US National Museum), Frankfurt (Senckenberg Museum), St. Petersburg (VNIGRI), Oslo, Tokyo, Naples, Vienna, etc., some of which are of historical importance but now inactive, as opposed to London, Washington and Frankfurt where the collections continue to be researched and supplemented. In recent decades, new collections have been actively developed in Japan (Shizuoka), Brazil (Brasilia) and China (Nanjing). A full account of international ostracod collections and their condition is needed. There are relatively few on-line resources where details of these collections can be found quickly and easily, so a full account of international ostracod collections and their condition is needed. Easy access to and cross referencing this collections archive of past and present ostracod work by IRGO members will strengthen the scientific integrity of the work and will facilitate new collaborations for the future.

An interesting development of IRGO which recently emerged but very clearly expressed during the ISO-17 in Rome was the disappearance of the apparent cleavage between the communications of the community of Palaeozoic ostracod specialists and those of so-called "post-palaeozoists" ostracod specialists. If one remembers that at the 6th ISO meeting in Saalfelden, 1976, colleagues working on Palaeozoic ostracods initiated their own communication group, the IRGPO, now 2013 at the ISO-17 in Rome it was from the very beginning requested by one of us (SC) to have the lectures of IRGPO-members within the same hall with those of the "post-palaeozoists" and we heard convincing arguments during the lectures of our colleagues for the way it appears now that Palaeozoic ostracods had already in their basic limb 
morphology acquired features visible in the living related groups (Siveter, 2013). This situation opens an immense capacity of communication between all kinds of ostracodologists, "palaeozoists" and "post-palaeozoists", with further possibilities for cooperative research and participation of new generations.

If we look back from the present day (2013) over the past 50 years we note that from the original group of ostracodologists who participated 1963 to the ISO-1 only two colleagues are still with us, L. S. Kornicker and $\mathrm{H}$. J. Oertli. There is a middle age generation that started during the next 3-4 ISO meetings and a young generation working mainly with the latter group. As we showed this last group is active, involved in productive projects and, as this report tried to document, IRGO is very lively. Perhaps this feeling of "successful family" is due to the fact that IRGO with its regular meetings and additional extra-meeting communication is represented by a group of ostracodologists that is not too large, with many young and active participants and in this way it is easily to maintain personal contacts (HGU in Sd). Some of us express satisfaction at seeing students who enrolled in our courses, having become nowadays well established ostracodologists. These latter maintain a double relationship, on the one hand they cooperate with us, the former teachers, being colleagues and friends, on the other hand, they are actively transmitting their knowledge to a new generation of students, representing the ostracodologists of tomorrow.

We will conclude our essay with a feeling of gratitude to all the Ostracodophili who left us but offered so many and important scientific information. We dedicate these thoughts to them but also to the new generation of ostracod sympathisers. So the Shakespeare dictum used by one of the participants (C. W. Wagner) at the Naples' symposium 1963, during a discussion session (Puri Ed., 1964, p. 602), seems well suited for the positive continuation of the IRGO social activities too: "the play can go on and the actors can change".

\section{Acknowledgements}

We thank the following "Ostracodophili" mentioned in the note 2 for their support. P. Frenzel (Jena) is thanked for the permission to use one of the figures from his 2005 paper. H. Koerten (Amsterdam) is thanked for his expert advice concerning the sociological analysis we used. We are much indebted also to the journal's editor T. Corrège (Talence) who followed the project's development and advised on the preparation of the documents deposited in the Supplementary documents section. One of us (DLD) is grateful to M. Nasta (Brussels) for his suggestion to use the term ostracodophili with the connotation presented here and to G. Napoleone (Florence) for the many discussions and useful bibliographic data. M. Gross (Graz) and M. C. Cabral (Lisbon) read and commented a preliminary version of the manuscript. Finally, we acknowledge the competent and helpful comments of the two reviewers of the MS (I. Mazzini and an anonymous one) which led to a clear improvement of the final version.

\section{Appendix A. Supplementary data}

Supplementary data to this article can be found online at http://dx. doi.org/10.1016/j.palaeo.2014.08.016.

\section{References}

Abate, S., Barra, D., Aiello, G., Bonaduce, G., 1993. The genus Krithe Brady, Crosskey \& Robertson, 1874 (Crustacea: Ostracoda) in the Pliocene-Early Pleistocene of the M. San Nicola Section (Gela, Sicily). Bol. Soc. Paleontol. Ital. 32, 349-366.

Abe, K., Vannier, J., 1995. Functional morphology and significance of the circulatory system of Ostracoda exemplified by Vargula hilgendorfii (Myodocopida). Mar. Biol. $124,51-58$.

Adams, T.E., 2010. Global Village. In: Jackson, R.L. (Ed.), Encyclopaedia of Identity. Sage, Thousand Oaks CA, pp. 315-316.

Adolfsson, S., Michalakis, Y., Paczesniak, D., Bode, S.N.S., Butlin, R.K., Lamatsch, D.K. Martins, M.J.F., Schmit, O., Vandekerkhove, J., Jokela, J., 2009. Evaluation of elevated ploidy and asexual reproduction as alternative explanations for geographic parthenogenesis in Eucypris virens ostracods. Evolution 64, 986-997.
Aiello, G., Barra, D., 2001. Pliocene ostracod assemblages at the M PI 3-M Pl 4 boundary in the Capo Rossello borehole (Agrigento, Sicily). Bol. Soc. Paleontol. Ital. 40, 97-103.

Aiello, G., Barratttolo, F., Barra, D., Fiorito, G., Mazzarella, A., Raia, P., Viola, R., 2007. Fractal analysis of ostracod shell variability - A comparison with geometric and classic morphometrics. Acta Palaeontol. Pol. 52, 563-573.

Alvarez Zarikian, C.A., 2009. Data report: late Quaternary ostracodes at IODP Site U1314 (North Atlantic Ocean). In: Channell, J.E.T., Kanamatsu, T., Sato, T., Stein, R., Alvarez Zarikian, C.A., Malone, M.J., The Expedition 303/306 Scientists (Eds.), Proceedings IODP 303/306. Integrated Ocean Drilling Program Management International, Inc., College Station TX, pp. 1-22. http://dx.doi.org/10 2204/iodp.proc.303/306.213.2009.

Alvarez Zarikian, C.A., 2013. Ostracoda in deep ocean Cenozoic paleoceanography: from regions of deep water formation to ultraoligotrophic environments. Il Naturalista Siciliano 37, 35-38.

Alvarez Zarikian, C.A., Stepanova, A.Y., Grützner, J., 2009. Glacial-interglacial variability in deep sea ostracod assemblage composition at IODP Site U1314 in the subpolar North Atlantic. Mar. Geol. 258, 69-87.

Anadón, P., Gliozzi, E., Mazzini, I., 2002. Paleoenvironmental reconstruction of marginal marine environments from combined paleoecological and geochemical analyses on ostracods. In: Holmes, J.A., Chivas, A.R. (Eds.), The Ostracoda, Applications in Quaternary ResearchGeophysical Monograph. 131. American Geophysical Union, Washington DC, pp. 227-248.

Angel, M., 1990. Food in the deep Ocean. In: Whatley, R., Maybury, C. (Eds.), Ostracoda and Global Events. Chapman \& Hall, London, pp. 273-285.

Athersuch, J., Bonaduce, J., 1976. Loculicyteretta pavonia (Brady). Publicazioni della Stazione Zoologica di Napoli 40, 349-364.

Athersuch, J., Horne, D.J., Whittaker, J.E., 1989. Marine and brackish water ostracods (Superfamilies Cypridacea and Cytheracea). E.J. Brill, Leiden.

Ayress, M., Neil, H., Passlow, V., Swanson, K., 1997. Benthonic ostracods and deep watermasses; a qualitative comparison of southwest Pacific, Southern and Atlantic Oceans. Palaeogeogr. Palaeoclimatol. Palaeoecol. 131, 287-302.

Baltanás, A., Danielopol, D.L., 2011. Geometric morphometrics and its use in ostracod research, a short guide. Joannea Geol. Paläontol. 11, 235-272.

Baltanás, A., Montes, C., Martino, P., 1990. Distribution patterns of ostracods in Iberian saline lakes. Influence of ecological factors. Hydrobiologia 197, 207-220.

Baltanás, A., Namiotko, T., Danielopol, D.L., 2000. Biogeography and disparity within the genus Cryptocandona (Crustacea, Ostracoda). Vie et Milieu 50, 297-310.

Baltanás, A., Brauneis, W., Danielopol, D.L., Linhart, J., 2003. Morphometric methods for applied ostracodology; tools for outline analysis of nonmarine ostracodes. In: Park L.E., Smith, A.J. (Eds.), Bridging the gap; trends in the ostracode biological and geological sciences. The Paleontological Society Papers. 9, pp. 101-118.

Barbeito-Gonzàlez, P.J., 1971. Die Ostracoden des Küstenbereiches von Naxos (Griechenland) und ihre Lebensbereiche. Mitt. Hamburg. Zool. Mus. Inst. 67, 255-326.

Bate, R.H., 1972. Phosphatized ostracods with appendages from the Lower Cretaceous of Brazil. Palaeontology 15, 379-393.

Bate, R.H., 1999. Non-marine ostracod assemblages of the Pre-Salt rift basins of West Africa and their role in sequence stratigraphy. In: Cameron, N.H., Bate, R.H., Clure, V.S. (Eds.), The oil and gas habitats of the South AtlanticGeol. Soc. Lond., Spec. Publ. 153, 283-292.

Bate, R.H., Robinson, E. (Eds.), 1978. A Stratigraphic Index of British Ostracoda. Seel House Press, Liverpool.

Becker, G., 2005. Functional morphology of Palaeozoic ostracods: phylogenetic implications. In: Ikeya, N., Tsukagoshi, A., Horne, D.J. (Eds.), Evolution and diversity of OstracodaHydrobiologia 538, 23-53.

Bennett, C., 2008. A review of the Carboniferous colonisation of non-marine environments by ostracods. Senckenb. Lethaea 88, 37-46.

Benson, R.H., 1969. Preliminary report on the study of abyssal ostracods. In: Neale, J.W (Ed.), The Taxonomy, Morphology and Ecology of Recent Ostracoda. Oliver \& Boyd, Edinburgh, pp. 475-480.

Benson, R.H., 1976. The evolution of the ostracode Costa analyzed by "theta-rho difference". In: Hartmann, G. (Ed.), Proceedings of the 5th International Symposium on Evolution of Post-Paleozoic Ostracoda. Abhandlungen und Verhandlungen der naturwissenschaftlichen Vereins in Hamburg (NF). 18/19 (Suppl.), pp. 127-139.

Benson, R.H., 1979. In search of lost oceans; a paradox of discovery. In: Gray, J., Boucot, A.J. (Eds.), Historical Biogeography, Plate Tectonics and Changing Environment. Oregon State University Press, Corvallis, pp. 379-389.

Benson, R.H., 1982a. From conversation with Peter: reminiscences of the philosophy of P.C. Sylvester-Bradley. In: Bate, R.H., Robinson, E., Shepard (Eds.), Fossil and Recent Ostracods. Ellis Horwood Ltd., Chichester, pp. 480-486.

Benson, R.H., 1982b. Deformation, Da Vinci's concept of form and the analysis of events in evolutionary history. In: Gallitelli, E.M. (Ed.), Proceedings of the 1st International Meeting on PalaeontologyEssential of Historical Geology. S.T.E.M. Mucchi, Modena, pp. 241-278.

Benson, R.H., 1984a. Perfection, continuity and common sense in historical geology. In: Berggren, W.A., Van Couvering, J.A. (Eds.), Catastrophes and Earth History; The New Uniformitarianism. Princeton University Press, Princeton, NJ, pp. 35-75.

Benson, R.H., 1984b. The Phanerozoic "crisis" as viewed from the Miocene. In: Berggren, W.A., Van Couvering, J.A. (Eds.), Catastrophes and Earth History; The New Uniformitarianism. Princeton University Press, Princeton, NJ, pp. 437-446.

Benson, R.H., 2004. Giuliano Ruggieri in the 60's and 70's and the Messinian Salinity Crisis; from an American friend's point of view. In: Gliozzi, E., Russo, A. (Eds.), Proceedings of the 1st meeting of the Italian ostracodologists "in memory of Giuliano Ruggieri"Bol. Soc. Paleontol. Ital. 43, 1-9.

Benson, R.H., Peypouquet, J.-P., 1983. The upper and mid-bathyal cenozoic ostracode faunas of the Rio Grande rise found on Leg 72 Deep Sea Drilling Project. Initial Rep. Deep Sea Drill. Proj. 72, 805-818. 
Benson, R.H., Ruggieri, G., 1974. The end of the Miocene, a time of crisis in TethysMediterranean history. Ann. Geol. Surv. Egypt 4, 237-250.

Benson, R.H., Sylvester-Bradley, P.C., 1971. Deep-sea ostracodes and the transformation of ocean to sea in the Tethys. In: Oertli, H.J. (Ed.), Colloque sur la Paléoécologie des Ostracodes/Colloquium on the Paleoecology of Ostracodes. Bulletin du Centre de Recherches Pau-SNPA. 5 (Supplément), pp. 63-91.

Benson, R.H., Rakic-El Bied, K., Bonaduce, G., 1991. An important current reversal (influx) in the Rifian Corridor (Morocco) at the Tortonian-Messinian boundary: the end of Tethys Ocean. Paleoceanography 6, 165.192.

Berggren, W.A., Van Couvering, J.A. (Eds.), 1984. Catastrophes and Earth History; The New Uniformitarianism. Princeton University Press, Princeton, N].

Bode, S.N.S., Adolsson, S., Lamatsch, D.K., Martins, M.J.S., Schmit, O., Vandekerkhove, J., Mezquita, F., Namiotko, T., Rossetti, G., Schön, I., Butlin, R.K., Martens, K., 2010 Exceptional cryptic diversity and multiple origins of parthenogenesis in a freshwater ostracod. Mol. Phylogenet. Evol. 54, 542-552.

Bodergat, A.M., Carbonnel, G., Rio, M., Keyser, D., 1993. Chemical composition of Leptocythere psammophila (Crustacea, Ostracoda) as influenced by winter metabolism and summer supplies. Mar. Biol. 117, 53-62.

Bonaduce, G., Russo, A., 1984. The Miocene ostracodes of Sardinia. Bol. Soc. Paleontol. Ital. 23, 421-437.

Bonaduce, G., Sgarrella, F., 1999. Paleoecological interpretation of the latest Messinian sediments from southern Sicily (Italy). Mem. Soc. Geol. Ital. 54, 83-91.

Bonaduce, G., Ciampo, G., Masoli, M., 1975. Distribution of Ostracoda in the Adriatic Sea. Publ. Stn. Zool. Napoli 40, 1-304.

Bonaduce, G., Ciliberto, B., Masoli, M., Minichelli, G., Pugliese, N., 1982. Systematics and distribution of the Family Policopidae in the Gulf of Naples. In: Bate, R.H., Robinson, E., Shepard, L. (Eds.), Fossil and Recent Ostracods. Ellis Horwood Ltd., Chichester pp. 344-364.

Bonaduce, G., Ruggieri, G., Russo, A., 1988. New ostracode genera of the Mediterranean Miocene. Bol. Soc. Paleontol. Ital. 27, 349-360.

Boomer, I., Aladin, N., Plotnikov, I., Whatley, R., 2000. The palaeolimnology of the Aral Sea: a review. Quat. Sci. Rev. 19, 1259-1278.

Boomer, I., von Grafenstein, U., Guichard, F., Bieda, S., 2005. Modern and Holocene sublittoral ostracod assemblages (Crustacea) from the Caspian Sea: a unique brackish, deep-water environment. Palaeogeogr. Palaeoclimatol. Palaeoecol. 225, 173-186.

Bossio, A., Cerri, R., Mazzei, R., Salvatorini, G., Sandrelli, F., 1996. Geologia dell'are Spicchiaiola-Pigniano (settore orientale del Bacino di Volterra). Bol. Soc. Geol. Ital. $115,393-422$.

Bottjer, D.J., Corrège, T., Kershaw, A.P., Surlik, F., 2006. Exploring life and environments through time: celebrating the 40th anniversary of Palaeo-3. Palaeogeogr. Palaeoclimatol. Palaeoecol. 232, 97-98.

Brady, G.S., 1880. Report on the Ostracoda dredged by H.M.S. Challenger during the years 1873-76. Report on the scientific results of the Voyage of H.M.S. Challenger 8,1-184

Brandão, S.N., 2008. First record of a living Platycopida (Crustacea, Ostracoda) from Antarctic waters and a discussion on Cytherella serratula (Brady, 1880). Zootaxa 1866 349-372.

Brandão, S.N., Horne, D.J., 2009. The platycopid signal of oxygen depletion in the ocean: critical evaluation of the evidence from modern ostracod biology, ecology and depth distribution. Palaeogeogr. Palaeoclimatol. Palaeoecol. 283, 126-133.

Brandão, S.N., Jan Sauer, J., Schön, I., 2010. Circumantarctic distribution in Southern Ocean benthos? A genetic test using the genus Macroscapha (Crustacea, Ostracoda) as a model. Mol. Phylogenet. Evol. 55, 1055-1069.

Bronstein, Z.S., 1947. Freshwater Ostracoda. Fauna of the USSRCrustacea: Ostracoda of Freshwaters. vol. 2 (1). Academy of Sciences of the USSR, Moscow, pp. 1-420 (translated and published by the US Department of the Interior, NSF, Washington D.C., 1988).

Bullard, E.C., 1975. Overview of plate tectonics. In: Fischer, A.G., Judson, S. (Eds.) Petroleum and Global Tectonics. Princeton University Press, Princeton NJ, pp. 5-19.

Cabral, M.C., Colin, J.-P., 1998. Nouvelles espèces de Limnocytheridae (ostracodes limniques) dans l'Aptien du Portugal: systématique et paléoécologie. Rev. Micropaleontol. 41, 269-279.

Cabral, M.C., Colin, J.-P., Carbonel, P., 2005. Espèces pléistocènes de la famille Darwinulidae Brady et Norman, 1889 (Ostracodes), en Algarve, sud Portugal. Rev. Micropaleontol. 48, 51-62.

Cadot, H.M., Van Schmus, W.R., Kaesler, R.L., 1972. Magnesium in calcite of marine Ostracoda. Bull. Geol. Soc. Am. 83, 3519-3522.

Carbonel, P., 1983. Ostracodes et paléohydrologie. In: Petit-Maire, N. (Ed.), Sahara ou Sahel? Quaternaire Recent du Bassin de Taoudenni (Mali). Editions du CNRS, pp. 173-179.

Carbonel, P., Farmer, M., 1990. The chemical composition of carapace of Cytherissa. In: Danielopol, D.L., Carbonel, P., Colin, J.-P. (Eds.), Cytherissa (Ostracoda) - the Drosophila of paleolimnology. Bulletin de l'Institut de Géologie du Bassin d'Aquitaine. 47-48, pp. 261-266.

Carbonel, P., Colin, J.-P., Danielopol, D.L., Löffler, H., Neustrueva, I., 1988. Paeoecology of limnic ostracodes; a review of some major topics. Palaeogeogr. Palaeoclimatol. Palaeoecol. 62, 413-461.

Chivas, A.R., De Deckker, P., Shelley, M.G., 1986. Magnesium and strontium in non-marine ostracod shells as indicators of palaeosalinity and palaeotemperature. Hydrobiologia $143,135-142$

Coles, G., Ayress, M., Whatley, R., 1990. A comparison of North Atlantic and Pacific Cainozoic deep-sea Ostracoda. In: Whatley, R., Maybury, C. (Eds.), Ostracoda and Global Events. Chapman \& Hall, London, pp. 287-305.

Coles, G.P., Whatley, R.C., Moguilevsky, A., 1994. The ostracod genus Krithe from the Tertiary and Quaternary of the North Atlantic. Palaeontology 37, 71-120.

Colin, J.-P., Dépêche, F., 1997. Faunes d'Ostracodes lacustres des bassins intra-cratoniques d'âge Albo-Aptien en Afrique de l'Ouest (Cameroun, Tchad) et au Brésil. Afr. Geosci. Rev. 4, 431-450.
Colin, J.-P., Cabral, M.C., Dépêche, F., Mette, W., 2000. Sinuocythere n. gen. (Ostracoda, Limnocytheridae, Timriaseviinae), a new genus of limnic ostracode from southern Tethyan Middle and Upper Jurassic. Micropaleontology 46, 123-134.

Corbari, L., 2004. Physiologie respiratoire, comportementale et morpho-fonctionnelle des Ostracodes Podocopes et Myodocopes et d'un Amphipode caprellidé profond. Stratégies adaptatives et implications évolutives,pp. 1-134, (Thèse de Doctorat Université Bordeaux 1. Nr. d'ordre 2885).

Corrège, T., De Deckker, P., 1997. Faunal and geochemical evidence for changes in intermediate water temperature and salinity in the western' Coral Sea (northeast Australia) during the Late Quaternary. Palaeogeogr. Palaeoclimatol. Palaeoecol. 313, 183-205.

Coupland, D., 2011. Marshall McLuhan. J.G. Cotta'sche Buchhandlung Nachfolger, Stuttgart.

Coviaga, C., Cusminsky, G., Pérez, A.P., Diaz, A., Schwalb, A., Alperin, M., Viehberg, F., Whatley, R., Ariztegui, D., Markgraf, V., 2013. Distribution and ecology of freshwater ostracods from northern Patagonia: an approach. Il Naturalista Siciliano 37, 83-84.

Cronin, T.M., Boomer, I., Dwyer, G.S., Rodriguez-Lazaro, J., 2002. Ostracoda and palaeoceanography. In: Holmes, J.A., Chivas, A.R. (Eds.), The Ostracoda; applications in Quaternary researchGeophysical Monograph. 131. American Geophysical Union, Washington DC, pp. 99-120.

Cronin, T.M., Dwyer, G.S., Kamiya, T., Schwede, S., Willard, D.A., 2003. Medieval Warm Period, Little Ice Age and 20th century temperature variability from Chesapeake Bay. Glob. Planet. Chang. 36, 17-29.

Cronin, T.M., Dwyer, G.S., Kamiya, T., Belkin, H., Vann, C.D., Schwede, S., Wagner, S.R., 2005. Ecology and shell chemistry of Loxoconcha matagordensis. Palaeogeogr. Palaeoclimatol. Palaeoecol. 225, 14-67.

Curry, B.B., 1999. An environmental tolerance index for ostracodes as indicators and chemical factors in aquatic habitats. Palaeogeogr. Palaeoclimatol. Palaeoecol. 148, $51-64$

Curry, B.B., Smith, A.J., 2012. NACODe (North American Combined Ostracode Database); introduction and application. Kölner Forum Geol. Paläontol. 21, 10.

Cusminsky, G., Schwalb, A., Pérez, A.P., Pineda, D., Viehberg, F., Whatley, R., Markgraf, V., Gilli, A., Ariztegui, D., Anselmetti, F.S., 2011. Late Ouaternary environmental changes in Patagonia as inferred from lacustrine fossil and extant ostracods. Biol. J. Linn. Soc. 103, 397-408.

Cytherissa (Ostracoda) - the Drosophila of paleolimnology. In: Danielopol, D.L., Carbonel, P., Colin, J.-P. (Eds.), Bulletin de l'Institut de Géologie du Bassin d'Aquitaine. 47-48, pp. 1-310.

Danielopol, D.L., Buttinger, R., Pipík, R., Gross, M., Olteanu, R., Knoblechner, J., 2008. "Hungarocypris" species of Lake Pannon (Central and South-Eastern Europe) transferred to Herpetocyprella Daday, 1909 (Ostracoda, Cyprididae). Senckenb. Lethaea 88, 147-160.

De Deckker, P., Forester, R.M., 1988. The use of ostracods to reconstruct continental palaeoenvironments. In: De Deckker, P., Colin, J.-P., Peypouquet, J.-P. (Eds.), Ostracoda in the Earth Sciences. Elsevier, Amsterdam, pp. 175-199.

De Deckker, P., Martens, K., 2013. Extraordinary morphological changes in valve morphology during the ontogeny of several species of the Australian ostracod genus Bennelongia (Crustacea, Ostracoda). Eur. J. Taxon. 36, 1-37.

De Deckker, P., Colin, J.-P., Peypouquet, J.-P. (Eds.), 1988. Ostracoda in the Earth Sciences. Elsevier, Amsterdam.

De Deckker, P., Chivas, A.R., Shelley, J.M.G., 1999. The uptake of Mg and Sr in the euryhaline ostracod Cyprideis determined from in vitro experiments. Palaeogeogr. Palaeoclimatol. Palaeoecol. 148, 105-116.

Delorme, L.D., 1969. Ostracods as Quaternary paleoecological indicators. Can. J. Earth Sci. $6,1471-1476$.

Demal, J., Rome, D.R., 1953. Les plages argentophiles chez les ostracodes. Bull. Acad. R. Belg. Cl. Sci. 5e Sér. 39, 340-347.

Dingle, R.V., 2003. Some palaeontological implications of putative, long-term, gene reactivation. J. Geol. Soc. Lond. 160, 815-818.

Dingle, R.V., Lord, A., 1990. Benthic ostracods and deep water-masses in the Atlantic Ocean. Palaeogeogr. Palaeoclimatol. Palaeoecol. 80, 213-235.

Do Carmo, D.A., Rafael, R.M.L., Vilhena, R.M., Tomassi, H.Z., 2004. Redescrição de Theriosynoecum silvai e Darwinula martinsi. Membro Crato. (Formação Santana), Cretáceo inferior, Bacia de araripe, NE Brasil. Rev. Bras. Paleontol. 7, 151-158.

Do Carmo, D.A., Meirelles, R.P., Suarez, P.A.Z., Mello, V.M., 2009. Size variations of the vestibula of Krithe gnoma Do Carmo \& Sanguinetti 1999 (Ostracoda): a new procedure for their analysis. Carnets de Géologie - Article 2009/09 (CG2009_A09), pp. 1-9.

Do Carmo, D.A., Colin, J.-P., Hidalgo, P.H.P., Meireles, R.P., Berbert-Born, M.L.C., De Almeida, C.M., 2012. Reassessment of the genus Sergipella Krömmelbein, 1967 (Ostracoda, Trachyleberididae), uppermost Aptian-Albian of Brazil and West Africa: taxonomy and paleogeographic distribution. Rev. Micropaleontol. 55, 3-15.

Durazzi, J.T., 1977. Stable isotopes in the ostracod shell: a preliminary study. Geochim. Cosmochim. Acta 41, 1168-1170.

Dwyer, G.S., Cronin, T.M., Baker, P.A., 2002. Trace elements in marine ostracodes. In: Holmes, J.A., Chivas, A.R. (Eds.), The Ostracoda; applications in Quaternary researchGeophysical Monograph. 131. American Geophysical Union, Washington, DC, pp. 205-225

Eldredge, N., Grene, M., 1992. Interactions; The Biological Context of Social Systems. Columbia University Press, New York

Elofson, O., 1941. Zur kenntnis des marinen Ostracoden Schwedens mit besonderer Berücksichtigung des Skagerak. Zoologica Bidrag frän Uppsala. 19, pp. 1-270 (translated into English by Israel Program for Scientific Tranlation, 1969).

Evolutionary biology of Ostracoda, its fundamentals and applications. 1988. In: Hanai, T., Ikeya, N., Ishizaki, K. (Eds.), Proceedings of the 9th International Symposium on 
Ostracoda, Developmentals in Palaeontology and Stratigraphy, 11. Elsevier Kodansha, Tokyo.

Feyerabend, P., 1999. Conquest of Abundance; A Tale of Abstraction versus the Richness of Being. The University of Chicago Press, Chicago.

Fischer, A.G., 1981. Climatic oscillations in the biosphere. In: Nitecki, M.H. (Ed.), Biotic Crises in Ecological and Evolutionary Time. Academic Press, New York, pp. 103-131.

Forester, R.M., Colman, S.M., Reynolds, R.L., Keigwin, L.D., 1994. Lake Michigan's Late Quaternary limnological and climate history from ostracode oxygen isotope and magnetic susceptibility. J. Great Lakes Res. 20, 93-107.

Frenzel, P., Boomer, I., 2005. The use of ostracods from marginal marine, brackish waters as bioindicators of modern and Quaternary environmental change. Palaeogeogr. Palaeoclimatol. Palaeoecol. 225, 68-92.

Frenzel, P., Wrozyna, C., Xie, M., Zhu, L., Schwalb, A., 2010. Palaeo-water depth estimation for a 600 -year record from Nam Co (Tibet) using an ostracod-based transfer function. Quat. Int. 218, 157-165.

Frenzel, P., Schulze, I., Pint, A., 2012. Cyprideis torosa valves (Ostracoda), a proxy for salinity? New data from field observations and a long-term microcosm experiment. In: Danielopol, D.L., Gross, M., Piller, W.E., Walz, N. (Eds.), Ostracodology-between tradition and renewallnt. Rev. Hydrobiol. 97, 314-329.

Ghetti, P., Anadon, P., Bertini, A., Esu, D., Gliozzi, E., Rook, L., Soulié-Märsche, I., 2002. The Early Messinian Velona basin (Siena, central Italy: paleoenvironmental and paleobiogeographical reconstructions. Palaeogeogr. Palaeoclimatol. Palaeoecol. 187, 1-33.

Gliozzi, E., Mazzini, I., 1998. Mixtacandona talianae n. sp. (Crustacea, Ostracoda) from the Holocene of Grotta del Lago (Umbria, central Italy). Micropaleontology 44, 441-446.

Gliozzi, E., Russo, A. (Eds.), 2004. Proceedings of the 1st meeting of the Italian ostracodologists, "in memory of Giuliano Ruggieri". Bolletino della Socità Paleontologica Italiana. 43, pp. 1-343.

Gliozzi, E., Rodriguez-Lazaro, J., Nachite, D., Martin-Rubio, M., Bekkali, R., 2005. An overview of Neogene brackish leptocytherids from Italy and Spain: biochronological and palaeogeographical implications. Palaeogeogr. Palaeoclimatol. Palaeoecol. 225, 283-301.

Gliozzi, E., Aladin, N., Boomer, I., Dimitrieva, T., Dykan, N., Schornikov, E.I., Stoica, M., Tesakova, E., 2013. Taxonomic revision of Livental's species of brackish water Ostracoda (Crustacea) and designation of neotypes. Il Naturalista Siciliano 37, 147-149.

Gray, J.S., 2001. Marine diversity; the paradigms in patterns of species richness examined. Sci. Mar. 65 (Suppl. 2), 41-56.

Grékoff, N., 1957. Ostracodes du basin du Congo - I. Jurassique supérieur et Crétacé inférieur du nord du Bassin. Ann. Musée R. Congo Belg. Sér. 8 Sci. Géol. 19, 1-170.

Grékoff, N., Krömmelbein, K., 1967. Étude comparée des ostracodes mésozoïques continenteaux des bassins atlantiques: série de Cocobeach, Gabon et série de Bahia, Brésil. Rev. Inst. Fr. Pétrol. 22, 1307-1353.

Griffiths, H.I., 1999. Freshwater Ostracoda from the mesolithic lake site at Lough Boora, Co. Offaly, Ireland. Irish J. Earth Sci. 17, 39-49.

Grosdidier, E., 1967. Quelques Ostracodes nouveaux de la Série anté-salifère ("Wealdienne") des bassins côtiers du Gabon et du Congo. Rev. Micropaleontol. 10, $107-118$.

Gross, M., Ramos, M.I., Caporaletti, M., Piller, W.E., 2013. Ostracods (Crustacea) and their palaeoenvironmental implication for the Solimões Formation (Late Miocene; Western Amazonia/Brazil). J. S. Am. Earth Sci. 42, 216-241.

Grossi, F., Gliozzi, E., Cosentino, D., 2011. Paratethyan ostracod immigrants mark the biostratigraphy of the Messinin Salinty Crisis. Joannea Geol. Paläontol. 11, 66-68.

Hartmann, G., 1964. Neontological and paleontological classification of Ostracoda. In: Puri, H.S. (Ed.), Ostracods as ecological and palaeoecological indicators. Publicazioni della Stazione Zoologica di Napoli. 33 (Supplemento), pp. 550-587.

Hartmann, G., Puri, H.S., 1974. Summary of neontological and paleontological classification of Ostracoda. Mitt. Hamburg. Zool. Mus. Inst. 70, 7-73.

Hartmann, G. (Ed.), 1976. Evolution of post-paleozoic ostracoda. Abh.Verh.Naturwiss. Vereins in Hamburg (NF), 18/19 (Suppl.), pp. 1-336 Paul Parey Verlag, Hamburg.

Heidegger, M., 1986. Umanesimo e scienza nell'era atomica. Editrice La Scuola, Brescia.

Holmes, J.A., Chivas, A.R. (Eds.), 2002. The Ostracoda; applications in Quaternary researchGeophysical Monograph. American Geophysical Union, Washington, DC, p. 131.

Horne, D.J., 2005. Homology and homoeomorphy in ostracod limbs. In: Ikeya, N., Tsukagoshi, A., Horne, D.J. (Eds.), Evolution and diversity of OstracodaHydrobiologia 538, 55-80.

Horne, D.J., 2010. Talking about a re-evolution: blind alleys in ostracod phylogeny. J. Micropalaeontol. 29, 81-85.

Horne, D.J., Lord, A., 2010. The 2009 recipient of the Brady Medal: Dr Thomas M. Cronin. J. Micropalaeontol. 29, 181-183.

Horne, D.J., Baltanás, A., Paris, G., 1998. Geographical distribution of reproductive modes in living non-marine ostracods. In: Martens, K. (Ed.), Evolutionary Ecology of Reproductive Modes in Non-marine Ostracods. Backhuys Publishers, Leiden, pp. 77-99.

Horne, D.J., Curry, B.B., Delorme, D., Martens, K., Smith, A., Smith, R.J., 2011a. Joannea Geol. Paläontol. 11, 80-84.

Horne, D.J., Brandão, S.N., Slipper, IJ., 2011b. The Platycopid Signal deciphered; responses of ostracod taxa to environmental change during the Cenomanian-Turonian Boundary Event (Late Cretaceous) in SE England. Palaeogeogr. Palaeoclimatol. Palaeoecol. 308, 304-312.

Horne, D.J., Holmes, J.A., Rodriguez-Lazaro, J., Viehberg, F.A. (Eds.), 2012. Ostracoda as proxies for Quaternary climate changeDevelopments in Quaternary Science. 17. Elsevier, Amsterdam.

Hou, X.G., Siveter, D.J., Williams, M., Walossek, D., Bergström, J., 1996. Appendages of the arthropod Kunmingella from the early Cambrian of China: its bearing on the systematic position of the Bradorida and the fossil record of the Ostracoda. Philos. Trans. R. Soc. Lond. B351, 1131-1145.

Hou, X.G., Williams, M., Siveter, D.J., Siveter, D.J., Aldridge, R.J., Sansom, R.S., 2010. Softpart anatomy of the Early Cambrian bivalved arthropods Kunyangella and Kunmingella: significance for the phylogenetic relationships of Bradoriida. Proc. R. Soc. Lond. B 277, 1835-1841.

Hsü, K.J., 1983. The Mediterranean was a Desert; A Voyage of the Glomar Challenger Princeton University Press, Princeton, NJ.

Hulings, N.C., Gray, J.S. (Eds.), 1971. A manual for the study of meiofauna. Smithsonian Contributions to Zoology. 78, pp. 1-84.

Hull, D.L., 1988. Science as a Process; An Evolutionary Account of the Social and Conceptual Development of Science. The University Chicago Press, Chicago.

Hunt, H., Cronin, T.M., Roy, K., 2005. Species-energy relationship in the deep sea: a test using the Quaternary fossil record. Ecol. Lett. 8, 739-747.

Iepure, S., Namiotko, T., Valdecasas, A.G., Magyari, E.K., 2012. Exceptionally wellpreserved giant spermatozoa in male and female specimens of an ostracod Cypria ophtalmica (Crustacea: Ostracoda) from Late Glacial lacustrine sediments of Southern Carpathians, Romania. Naturwissenschaften 99, 587-590.

Ikeya, N., Tsukagoshi, A., Horne, D.J. (Eds.), 2005. Evolution and diversity of Ostracoda. Hydrobiologia. 538, pp. 1-265.

Italian Ostracodologists Group, International Research Group on Ostracoda, 2013. 17th International Symposium on Ostracoda "Back to the Future" (http://www.Uniroma3.it/ news2.php? news $=3708 \& \mathrm{p}=1$ )

Jacobzone, M., Carbonnel, G., 1971. Coéfficient de Jaccard et coéfficient de correlation: application aux Ostracodes miocènes. In: Oertli, H.J. (Ed.), Colloque sur la Paléoécologie des Ostracodes/Colloquium on the Paleoecology of Ostracodes. Bulletin du Centre de Recherches Pau-SNPA. 5 (Supplément), pp. 167-178.

Kaesler, R.L., 1969. Numerical taxonomy of selected recent British Ostracoda. In: Neale, J.W. (Ed.), The Taxonomy, Morphology and Ecology of Recent Ostracoda. Oliver \& Boyd, Edinburgh, pp. 21-47.

Kaesler, R.L., 1983. Usefullness of Ostracoda. In: Maddocks, R.F. (Ed.), Applications of Ostracoda - Proceedings of the 8th International Symposium on Ostracoda Department of Geosciences. University of Houston TX, pp. 8-18.

Kaesler, R.L., Lohmann, K.C., 1976. Phenotypic variations of populations of Krithe producta with environment. In: Hartmann, G. (Ed.), Proceedings of the 5th International Symposium on evolution of Post-Paleozoic Ostracoda. Abhandlungen und Verhandlungen des Naturwissenschaftlichen Vereins in Hamburg (NF). 18/19 (Suppl.), pp. 279-286.

Kaesler, R.L., Maddocks, R.F., 1987. Preliminary harmonic analysis of outlines of recent macrocypridid Ostracoda. In: Krstić, N. (Ed.), Symposium on ostracodes. Taxonomy, Biostratigraphy and Distribution of Ostracodes. 2, pp. 169-174.

Kaesler, R.L., Taylor, R.S., 1971. Cluster analysis and ordination in paleoecology of Ostracoda from Green River Formation (Eocene, USA). In: Oertli, H.J. (Ed.), Colloque sur la Paléoécologie des Ostracodes/Colloquium on the Paleoecology of Ostracodes. Bulletin du Centre de Recherches Pau-SNPA. 5 (Supplément), pp. 153-166.

Kempf, E., 1980-2013. Index and bibliography of nonmarine and marine Ostracoda. 27 volumes. Sonderveröffentlichungen des Geologischen Instituts der Universität zu Köln. or CD-ROMAvailable from http;//ostracoda-on.tripod.com (Accessed July 7 , 2014).

Kesling, R.V., 1951. The morphology of ostraco molt stages. Ill. Biol. Monogr. 21, 1-126.

Kesling, R.V., 1983. Ostracodology in 1982. In: Maddocks, R.F. (Ed.), Applications of Ostracoda - Proceedings of the 8th International Symposium on Ostracoda. Department of Geosciences University of Houston Tx, pp. 1-7.

Keyser, D., Aladin, N., Plotnikov, I., 2004. Ostracods and their adjustment to saline environments. Mitt. Hamburg. Zool. Mus. Inst. 101, 157-167.

Koch, A., 2005. Autopoietic spatial systems; the significance of actor network theory and system theory for the development of a system theoretical approach of space. Soc. Geogr. 1, 5-14.

Koenders, A., Martens, K., Halse, S., Schön, I., 2012. Cryptic species of the Eucypris virens species complex (Ostracoda, Crustacea) have invaded western Australia. Biol. Invasions 14, 2187-2201.

Koerten, H., Veenswijk, M., 2010. The social construction of public infrastructure; the case of the Dutch National Geo-information Clearinghouse Project. Int. J. Bus. Anthropol. 1 $48-69$.

Krijgsman, W., Stoica, M., Vasiliev, I., Popov, V., 2010. Rise and fall of the Paratethys Sea during the Messinian salinity crisis. Earth Planet. Sci. Lett. 290, 183-191.

Krömmelbein, K., 1965. Neue, für Vergleiche mit West-Afrika wichtige Ostracoden-Arten der brasilianischen Bahia-Serie (Ober-Jura?/Unter-Kreide in Wealden-Fazies). Senckenb. Lethaea 46a, 177-213.

Krömmelbein, K., 1966a. On "Gondwana Wealden" Ostracoda from NE Brazil and West Africa. In: Van Hinte, J.E. (Ed.), Proceedings of the 2nd West African Micropaleontological Colloquium. E.J. Brill, Leiden, pp. 113-119.

Krömmelbein, K., 1966b. Probleme des Gondwanalandes. Zool. Anz. 177, 1-39.

Krömmelbein, K., 1967. Ostracoden aus der marinen "Küsten-Kreide" Brasiliens. 2: Sergipella transatlantica n. g., n. sp., und Aracajuia benderi n. g., n. sp., aus dem Ober-Aptium/ Albium. Senckenb. Lethaea 48, 525-533.

Latour, B., 2005. Reassembling the social. An Introduction to Actor-Network-TheoryOxford University Press, New York.

Latour, B., Woolgar, S., 1979. Laboratory Life; the Social Construction of Scientific Facts. Sage Publications, Beverly Hills CA.

Lauterbach, S., Brauer, A., Andersen, N., Danielopol, D.L., Dulski, P., Milecka, K., Namiotko, T., Obremska, M., von Grafenstein, U., Particpants, Declakes, 2011. Environmental responses to Lateglacial climatic fluctuations recorded in the sediments of pre-Alpine Lake Mondsee (northeastern Alps). J. Quat. Sci. 26, 253-267.

Lethiers, F., Whatley, R.C., 1994. The use of Ostracoda to reconstruct the oxygen levels of Late Palaeozoic oceans. Mar. Micropaleontol. 24, 57-69. 
Löffler, H., 1969. Recent and subfossil distribution of Cytherissa lacustris (Ostracoda) in Lake Constance. Mitt. Int. Ver. Theor. Angew. Limnol. 18, 240-251.

Löffler, H., 1975. The evolution of ostracod-fauna in alpine and prealpine lakes and their value as indicators. In: Swain, F.M., Kornicker, L.S., Lundin, R.F. (Eds.), Biology and paleobiology of ostracods, a symposiumBull. Am. Paleontol. 65 (282), 433-443.

Löffler, H., Danielopol, D. (Eds.), 1977. Aspects of ecology and zoogeography of recent and fossil OstracodaProceedings of the 6th International Symposium on Ostracods, Saalfelden (Salzburg), July 30-August 8, 1976. Dr. W. Junk b.v. Publishers, The Hague002E.

Lord, A., Horne, D.J., 2007. Ostracods, ancient and modern: a review of John Neale's scientific contribution. Proc. Yorks. Geol. Soc. 56, 267-270.

Lord, A., Cabral, M.C., Dambeck, R., Kunst, M., 2011. Ostracod evidence for the neolithic environment of Rioz Sizandro, Portugal. Palaeobiodivers. Palaeoenviron. 91, 215-228.

Maas, A., Waloszek, D., 2005. Phosphatocopina-ostracode-like sister group of Eucrustacea. In: Ikeya, N., Tsukagoshi, A., Horne, D.J. (Eds.), Evolution and diversity of OstracodaHydrobiologia 538, 139-152.

Maddocks, R.F., 1976. Quest for ancestral podocopid: numerical cladistics analysis of ostracode appendages; a preliminary report. In: Hartmann, G. (Ed.), Proceedings of the 5th International Symposium on Evolution of Post-Paleozoic Ostracoda. Abhandlungen und Verhandlungen des Naturwissenschaftlichen Vereins in Hamburg (NF). 18/19 (Suppl.), pp. 39-54.

Maddocks, R.F., 1982. Ostracoda. In: Abele, L. (Ed.), The biology of Crustacea 1Systematics, the Fossil Record and Biogeography. Academic Press, New York, pp. 221-239.

Majoran, S., Agrenius, S., Kucera1, M., 2000. The effect of temperature on shell size and growth rate in Krithe praetexta praetexta (Sars). In: Horne, D.J., Martens, K. (Eds.) Evolutionary biology and ecology of OstracodaHydrobiologia 419, 141-148.

Martens, K., 1985. Effects of temperature and salinity on postembryonic growth in Mytilocypris henricae (Crustacea, Ostracoda). J. Crustac. Biol. 5, 258-272.

Martens, K. (Ed.), 1998. Sex and Parthenogenesis-Evolutionary Ecology of Reproductive Modes in Non-marine Ostracods. Backhuys Publishers, Leiden.

Martens, K., Halse, S., Schön, I., 2012. Nine new species of Bennelongia De Deckker \& McKenzie, 1981 (Crustacea, Ostracoda) from Western Australia, with the description of a new subfamily. Eur. J. Taxon. 8, 1-56.

Matzke-Karasz, R., Schudack, M., Martens, K., 2007. Ostracodology in time and space; looking back on 15 International Symposia on Ostracoda, and the times in between. In: Matzke-Karasz, R., Schudack, M., Martens, K. (Eds.), Ostracodology - linking Bioand Geosciences. Proceedings of the 15th International Symposium on Ostracoda, Berlin, 2005. Developments in Hydrobiolgy 197, Hydrobiologia 585, 1-11.

Matzke-Karasz, R., Smith, R.J., Symonová, R., Miller, C.G., Tafforeau, P., 2009. Sexual intercourse involving giant sperm in Cretaceous ostracode. Science 324, 1535.

Matzke-Karasz, R., Neil, J.V., Smith, R.J., Godthelp, H., Archer, M., Hand, S.J., 2013. Ostracods (Crustacea) with soft part preservation from Miocene cave deposits of the Riversleigh World Heritage Area, NW Queensland, Australia. J. Syst. Palaeontol. 1-32. http://dx.doi.org/10.1080/14772019.2012.760007.

Matzke-Karasz, R., Neil, J.V., Smith, R.J., Symonová, R., Morkovský, L., Archer, M., Hand, S.J., Cloeters, P., Tafforeau, P., 2014. Subcellular preservation in giant ostracod sperm from an early Miocene cave deposit in Australia. Proc. R. Soc. B 281, 20140394. http://dx. doi.org/10.1098/rspb.2014.0394 (1-9).

Mazzini, I., Faranda, C., Giardini, M., Giraudi, C., Sadori, L., 2011. Late Holocene palaeoenvironmental evolution of the Roman harbour of Portus, Italy. J. Paleolimnol. $46,246-256$.

McKenzie, K.G., 1978. Shallow marine and freshwater Ostracoda of Tethys. Lethaia 11, 126.

McKenzie, K.G., 1987. Tethys and her progeny. In: McKenzie, K.G. (Ed.), Proceedings of the International Symposium on Shallow Tethys. 2. A.A. Balkema, Rotterdam, pp. 501-523.

McKenzie, K.G., Müller, K.J., Gramm, M.N., 1983. Phylogeny of Ostracoda. In: Schram, F. (Ed.), Crustacean Issues 1Crustacean Phylogeny. A.A. Balkema, Rotterdam, pp. 29-46.

McKenzie, K.J., Majoran, S., Emami, V., Reyment, R.A., 1989. The Krithe problem: first test of Peypouquet's hypothesis, with a redescription of Krithe praetexta praetexta (Crustacea, Ostracoda). Palaeogeogr. Palaeoclimatol. Palaeoecol. 74, 343-354.

Mezquita, F., Roca, J., Wansard, G., 1999. Moulting, survival and calcium uptake: the effects of temperature and water chemistry on an ostracod crustacean (Herpetocypri intermedia) under experimental conditions. Arch. Hydrobiol. 146, 219-238.

Mischke, S., Kramer, M., Zhang, C., Shang, H., Herzschuh, U., Erzinger, J., 2008. Reduced early Holocene moisture availability in the Bayan Har Mountains, north-eastern Tibetan Plateau, inferred from a multiproxy lake record. Palaeogeogr. Palaeoclimatol. Palaeoecol. 267, 59-76.

Mischke, S., Bössneck, U., Diekmann, B., Herzschuh, U., Jin, H., Kramer, A., Wünnemann, B., Zhang, C., 2010. Quantitative relationship between water-depth and sub-fossil ostracod assemblages in Lake Donggi Cona, Qinghai Province, China. J. Paleolimnol. 43, 589-609.

Moore, R.C. (Ed.), 1961. Treatise on Invertebrate Paleontology, Part Q Arthropoda 3Crustacea Ostracoda. Geological Society of America and University of Kansas Press, Kansas.

Müller, G.W., 1894. Die Ostracoden des Golfes von Neapel und der angrenzenden Meeresabschnitte. In: Zoologisches Station zu Neapel (Ed.), Fauna und Flora des Golfes von Neapel und der angrenzenden Meeres-abschnitteMonographie. 21. Friedländer \& Sohn, Berlin, pp. 1-404.

Müller, K.J., 1964. Ostracoda (Bradorina) mit phosphatischen Gehausen aus dem Oberkambrium von Schweden. N. Jb. Geol. Paläont. Abh. 121, 1-46.

Müller, K.J., 1979. Phosphatocopine ostracodes with preserved appendages from the Upper Cambrian of Sweden. Lethaia 12, 1-27.

Namiotko, T., Meisch, C., Gidó, Z., Danielopol, D.L., 2001. Redescription, taxonomy, distribution and ecology of Cryptocandona dudichi (Klie, 1930) (Crustacea, Ostracoda). Bull. Soc. Nat. Luxemb. 102, 109-130.
Namiotko, T., Danielopol, D.L., von Grafenstein, U., Lauterbach, S., Brauer, A., Andersen, N., Hüls, M., Milecka, K., Baltanás, A., Geiger, W., Declakes participants, 2013. Palaeoecology of ostracods from deep-lake Mondsee (Austria) as a source of ideas for new (palaeo-)biological research. Il Naturalista Siciliano 37, 245-246.

Neale, J.W. (Ed.), 1969. The Taxonomy, Morphology and Ecology of Recent Ostracoda. Oliver \& Boyd, Edinburgh

Neale, J.W., 1988. Ostracoda, a historical perspective. In: Hanai, T., Ikeya, N., Ishizaki, K. (Eds.), Evolutionary biology of Ostracoda, its fundamentals and applications. Proceedings of the 9th International Symposium on ostracodaDevelopmentals in Palaeontology and Stratigraphy. 11. Elsevier Kodansha, Tokyo, pp. 3-15.

Oakley, T.H., Wolfe, J.M., Lindgren, A.R., Zaharoff, A.K., 2012. Phylotranscriptomics to bring the understudied into the fold: monophyletic Ostracoda, fossil placement, and Pancrustacean phylogeny. Mol. Biol. Evol. 30, 215-233.

Oertli, H.J. (Ed.), 1971. Colloque sur la Paléoécologie des Ostracodes/Colloquium on the Paleoecology of OstracodesBulletin du Centre de Recherches Pau-SNPA. 5 (Supplément). Service Documentation SNPA, Pau

Oertli, H.J., 1982. Early research on Ostracoda and the French contribution. In: Bate, R.H., Robinson, E., Shepard (Eds.), Fossil and Recent Ostracods. Ellis Horwood Ltd., Chichester, pp. 454-478.

Oertli, H.J. (Ed.), 1985. Atlas des Ostracodes de France (Paléozoïque-Actuel). Bulletin du Centre de Rechérches, Exploration-Production, Elf-Aquitaine, Mémoire. 9 (Pau).

Oertli, H.J., Grosdidier, E., Le Fevre, J., 1983. Ostracoda in petroluem exploration. In: Maddocks, R.F. (Ed.), Applications of Ostracoda - Proceedings of the 8th International Symposium on Ostracoda. Department of Geosciences University of Houston Tx, pp. 19-34.

Olempska, E., Horne, D.J., Szaniawski, H., 2012. First record of preserved soft parts in a Palaeozoic podocopid (Metacopina) ostracod, Cytherellina submagna: phylogenetic implications. Proc. R. Soc. B 279, 564-570.

Ostracodophili, 2013. From Naples 1963 to Rome 2013 - A brief review of how the International Research Group on Ostracoda (IRGO) developed as a social communication system. Il Naturalista Siciliano 37, 13-17.

Bridging the gap; trends in the ostracode biological and geological sciences. In: Park, L.E., Smith, A.J. (Eds.), The Paleontological Society Papers. 9, pp. 1-290.

Perrier, V., 2012. An atypical Silurian myodocope ostracod from the Armorican Massif, France. Acta Palaeontol. Pol. 57, 363-373.

Perrier, V., Siveter, D.J., Williams, M., Lane, P., 2013. An early Silurian "Herefordshire" ostracod from Greenland. Il Naturalista Siciliano 37, 269-270.

Peypouquet, J.-P., 1975. Les variations des caractères morphologiques internes chez les Ostracodes des genres Krithe et Parakrithe; relations possibles avec la teneur en 0-2 dissous dans l'eau. Bull. Inst. Géol. Bassin Aquitaine 17, 81-88.

Peypouquet, J.-P., 1977. Les Ostracodes et la connaissance des paléomilieux profonds. Application au Cénozoïque de l'Atlantique oriental,pp. 1-443, (Thèse Doctorat ès-Sciences, Univérsité Bordeaux 1, Bordeaux, Nr. 552).

Peypouquet, J.-P., Carbonel, P., Ducasse, O., Tölderer-Farmer, M., Lété, C., 1988. Environmentally cued polymorphism of ostracods; a theoretical and practical approach; a contribution to geology and to the understanding of ostracod evolution. In: Hanai, T., Ikeya, N., Ishizaki, K. (Eds.), Evolutionary biology of Ostracoda, its fundamentals and applications. Proceedings of the 9th International Symposium on ostracodaDevelopmentals in Palaeontology and Stratigraphy. 11. Elsevier Kodansha, Tokyo, pp. 1003-1019.

Pietschmann, H., 1996. Phänomenologie der Naturwissenschaften. Springer Verlag, Berlin

Pinto, R.L., Rocha, C.E., Martens, K., 2005. On the evolution of the genus Microdarwinula Danielopol 1968 (Ostracoda, Darwinulidae) with the description of a new species from semi-terrestrial habitats in São Paulo state, Brazil. Crustaceana 78, 975-986

Poropat, S.F., Colin, J.-P., 2012. Early Cretaceous ostracod biostratigraphy of eastern Brazil and western Africa: an overview. Gondwana Res. http://dx.doi.org/10.1016/j.gr.2012. 06.002 .

Puri, H.S. (Ed.), 1964. Ostracods as ecological and palaeoecological indicators. Publicazioni della Stazione Zoologica di Napoli. 33 (Supplemento), pp. 1-612.

Puri, H.S., Bonaduce, G., Gervasio, A.M., 1969. Distribution of Ostracoda in the Mediterranean. In: Neale, J.W. (Ed.), The Taxonomy, Morphology and Ecology of Recent Ostracoda. Oliver \& Boyd, Edinburgh, pp. 356-411.

Reyment, R.A., 1963. Multivariate analytical treatement of quantitative species associations: an example from Palaeoecology. J. Anim. Ecol. 32, 535-547.

Fifth European Ostracodologists Meeting "Building bridges with ostrcods". In: RodriguezLazáro, J. (Ed.), Revista Española de micropaleontologia. 36, pp. 1-214.

Rodriguez-Lazáro, J., Cronin, T.M., 1999. Quaternary glacial and deglacial Ostracoda in the thermocline of Little Bahama Bank (NW Atlantic); palaeoceanographic implications. Palaeogeogr. Palaeoclimatol. Palaeoecol. 152, 339-364.

Rome, D.R., 1947. Herpetocypris reptans Baird. Etude morphologique et histologique. I. Morphologie externe et système nerveux. La Cellule 52, 51-152.

Ruggieri, G., 1967. The Miocene and later evolution of the Mediterranean Sea. Aspects of Tethyan biogeography. Syst. Assoc. Lond. 7, 283-290.

Ruggieri, G., Sprovieri, R., 1976. Messinian Salinity Crisis and its paeogeographical implications. Palaeogeogr. Palaeoclimatol. Palaeoecol. 20, 13-21.

Russo, A., 2004. Professor Giuliano Ruggieri (1919-2002). In: Gliozzi, E., Russo, A. (Eds.), Proceedings of the 1st meeting of the Italian ostracodologists "in memory of Giuliano Ruggieri"Bol. Soc. Paleontol. Ital. 43, I-III.

Sames, B., Horne, D.J., 2012. Latest Jurassic to Cretaceous non-marine ostracod biostratigraphy - unde venis, quo vadis? J. Stratigr. 36, 267-288.

Sandberg, P.A., Hay, W.W., 1967. Study of microfossils by means of the scanning electron microscope. J. Paleontol. 41, 999-1001.

Sars, G.O., 1922-1928. An account of Crustacea of Norway. Ostracoda. vol. 9. Bergen Museum, Bergen, pp. 1-277, (Parts 1-15). 
Schmit, O., Bode, S.N.S., Camacho, A., Horne, D.J., Lamatsch, D.K., Martens, K., Martins, M.J., Namiotko, T., Rossetti, G., Rueda-Sevilla, P.J., Schön, I., Vandekerkhove, J., Francesc Mesquita-Joanes, F., 2013. Linking present environment and the segregation of reproductive modes (geographical parthenogenesis) in Eucypris virens (Crustacea: Ostracoda). J. Biogeogr. 40, 2396-2408.

Schön, I., Martens, K., van Dijk, P. (Eds.), 2009. Lost sex. The Evolutionary Biology of Parthenogenesis. Springer, Dordrecht.

Schwalb, A., Lister, G.S., Kelts, K., 1994. Ostracode carbonate $\delta^{18} \mathrm{O}$ - and $\delta^{13} \mathrm{C}$-signature of hydrological and climatic changes affecting Lake Neuchâtel, Switzerland, since the latest Pleistocene. J. Paleolimnol. 1, 3-17.

Siveter, D.J., 2008. Ostracods in the Palaeozoic? Senckenb. Lethaea 88, 1-9.

Siveter, D.J., 2013. Origin and early history of ostracods. Il Naturalista Siciliano 37, 373-374.

Siveter, D.J., Sutton, M.D., Briggs, D.E.G., Siveter, D.J., 2003. An ostracod crustacean with soft parts from the Lower Silurian. Science 302, 1749-1751.

Smith, A.J., 1993. Lacustrine ostracod diversity and hydrochemistry in lakes of the northern Midwest of the United States. In: McKenzie, K.J., Jones, P.J. (Eds.), Ostracoda in the earth and life sciencesProceedings of the 11th International Symposium on Ostracoda. A.A. Balkema, Rotterdam, pp. 493-500.

Smith, R.J., 2000. Morphology and ontogeny of Cretaceous ostracods with preserved appendages from Brazil. Palaeontology 43, 63-98.

Sohn, I.G., 1977. Zoogeography of ostracodologists. In: Löffler, H., Danielopol, D. (Eds.), Aspects of ecology and zoogeography of recent and fossil OstracodaProceedings of the 6th International Symposium on ostracods, Saalfelden (Salzburg), July 30-August 8, 1976. Dr. W. Junk b.v. Publishers, The Hague, pp. 3-12.

Stoica, M., Lazăr, I., Krigigsman, W., Vasiliev, I., Jipa, D., Floroiu, A., 2013. Paleoenvironmental evolution of the East Carpathian foredeep during the late Miocene-early Pliocene (Dacian Basin; Romania). Glob. Planet. Chang. 103, 135-148.

Suzin, A.V., 1956. Ostracoda from Tertiary deposits of the North Caucasus. Gostoptekhizdat, Moscow, (in Russian)

Sylvester-Bradley, P.C., 1973. The new palaeontography. Stereo-Atlas of Ostracod Shells. 1, pp. 1-4.

Sylvester-Bradley, P.C., Benson, R.H., 1971. Terminology for surface features in ornate ostracodes. Lethaia 4, 249-286.

Syme, A.E., Oakley, T.H., 2012. Dispersal between shallow and abyssal seas and evolutionary loss and regain of compound eyes in cylindroleberidid ostracods: conflicting conclusions from different comparative methods. Syst. Biol. 61, 314-336.

Teichert, C., Yochelson, E.L., 1985. The International Palaeontological Association Historical perspectives. Episodes 8, 252-256.

Thenius, E., 1976. Allgemeine Paläontologie; Skriptum zur gleichnamigen Vorlesung von Prof. E. Thenius. Prugg Verlag, Wien.

Thenius, E., 1977. Meere und Länder im Wechsel der Zeiten; die Paläogeographie als Grundlage für die Biogeographie. Verständliche Wissenschaft. 114. Springer Verlag Berlin.

Triebel, E., 1968. Einige für das Gebiet neue Süßwasser-Ostracoden aus Deutschland. Nat. Mus. 98, 239-258.

Uffenorde, H., 1972. Ökologie und jahreszeitliche Verteilung rezenter, benthonischer Ostracoden des Limski kanal bei Rovinj (nördliche Adria). Gött. Arb. Geol. Paläontol. $13,1-121$.

Uffenorde, H., 1975. Dynamics in recent marine benthonic ostracode assemblages in the Limski Kanal (northern Adriatic Sea). In: Swain, F.M., Kornicker, L.S., Lundin, R.F. (Eds.), Biology and paleobiology of ostracods, a symposiumBull. Am. Paleontol. 65 (282), 147-165.

Van den Bold, W.A. (Ed.), 1974. Ostracoda. The Henry V. Howe Memorial Volume. Geoscience and Man. 6, pp. 1-182.

Van Harten, D., 1995. Differential food detection; a speculative reinterpretation of vestibule variability in Krithe (Crustacea, Ostracoda). In: Ríha, J. (Ed.), Ostracoda and
biostratigraphyProceedings of the 12 International Symposium on Ostracoda. A.A. Balkema, Rotterdam, pp. 33-36

Van Morkhoven, F.P.C.M., 1962/1963. Post-Palaeozoic Ostracods. Their Morphology, Taxonomy and Economic UseElsevier, Amsterdam, (Volume 1 General (1982); volume 2 Generic descriptions (1963))

Vannier, J., Abe, K., 1995. Size, body plan and respiration in the Ostracoda. Palaeontology $38,843-873$.

Vannier, J., Williams, M., Siveter, David J., 1997. The Cambrian origin of the circulatory system of crustaceans. Lethaia 30, 169-184.

Vesper, B., 1975. The problem of nodding on Cyprideis torosa (Jones 1850). In: Swain, F.M., Kornicker, L.S., Lundin, R.F. (Eds.), Biology and paleobiology of ostracods, a symposiumBull. Am. Paleontol. 65 (282), 225-244.

Von Grafenstein, U., 2002. Oxygen-isotope studies of ostracods from deep lakes. In: Holmes, J.A., Chivas, A.R. (Eds.), The Ostracoda; applications in Quaternary researchGeophysical Monograph. 131. American Geophysical Union, Washington, DC, pp. 249-266.

Vyalov, O.S., 1971. Fossil Ostracoda. Papers from the 1st All-Union Symposium on fossi Ostracoda (Lvov, 1963). Smithsonian Institution, Washington DC (Translated from Russian by the Israel Program for Scientific Translations).

Waddington, C.H., 1969. Behind Appearance. Edinburgh University Press, Edinburgh.

Walossek, D., 1999. On the Cambrian diversity of Crustacea. In: Schram, F.R., von Vaupe Klein, J.C. (Eds.), Crustacean and the biodiversity crisisProceedings of the 4th International Crustacean Congress. Brill Academic Publishers, Leiden, pp. 3-27.

Wansard, G., Mezquita, F., Roca, J., 1999. Experimental determination of strontium and magnesium partitioning in calcite of freshwater ostracod Herpetocypris intermedia. Arch. Hydrobiol. 145, 237-253.

Whatley, R., 1990. Ostracoda and global events. In: Whatley, R., Maybury, C. (Eds.) Ostracoda and Global Events. Chapman \& Hall, London, pp. 3-24.

Whatley, R. Zhao, 1993. The Krithe problem. A case history of the distribution of Krithe and Parakrithe (Crustacea, Ostracoda) in South China Sea. Palaeogeogr. Palaeoclimatol. Palaeoecol. 103, 281-292.

Whittaker, J.E., Hart, M.B. (Eds.), 2009. Ostracods in British Stratigraphy. The Micropalaeontological Society, Special Publications. The Geological Society, London.

Williams, M., Floyd, J.D., Salas, M.J., Siveter, D.J., Stone, P., Vannier, J.M.C., 2003. Patterns of ostracod migration for the "North Atlantic" region during the Ordovician. Palaeogeogr. Palaeoclimatol. Palaeoecol. 195, 193-228.

Williams, M., Siveter, D.J., Salas, M.J., Vannier, J., Popov, L., Pour, M.G., 2008. The earliest ostracods: the geological evidence. Senckenb. Lethaea 88, 11-21.

Williams, M., Vannier, J., Corbari, L., Massabuau, J.-C., 2011. Oxygen as a driver of early arthropod micro-benthos evolution. PLoS ONE 6, 1-13.

Wrozyna, C., Frenzel, P., Daut, G., Mäusbacher, R., Zhu, L., Schwalb, A., 2012. Holocene lake-level changes of Lake NamCo, Tibetan Plateau, deduced from ostracod assemblages and $\delta^{18} \mathrm{O}$ and $\delta^{13} \mathrm{C}$ signatures of their valves. In: Horne, D.J., Holmes, J. A., Rodriguez-Lazaro, J., Viehberg, F.A. (Eds.), Ostracoda as proxies for Quaternary climate changeDevelopments in Quaternary Science. 17. Elsevier, Amsterdam, pp. 281-296.

Yasuhara, M., Hunt, G., Cronin, T.M., Okahashia, H., 2009. Temporal latitudinal-gradient dynamics and tropical instability of deep-sea species diversity. PNAS 106, 21717-21720.

Yin, Y., Geiger, W., Martens, K., 1999. Effects of genotype and environment on phenotypic variability in Limnocythere inopinata (Crustacea, Ostracoda). Hydrobiologia 400 85-114.

Ziman, J., 1984. An Introduction to Science Studies; the Philosophical and Social Aspects of Science and Technology. Cambridge University Press, Cambridge. 